\title{
أساليب زخرفة الملابس في المنطقة الشرقية بالمهكة العربية السعودية
}

إعداد

د. لينا محمد عبد الله باحيد ره

أستاذ تاريخ الملابس والتطريز المساعد

كلية الفنون والتصميم الداخلي جامعة أم القرى القى

\author{
ه. رابعة سالم سجينحسـ \\ أستاذ تاريخ الملابس والتطريز المساعد \\ كلية الفنون والتصميم الداخلي \\ جامعة أم القرى
}

مجلة بحوث التربية النوعية ـ جامعة المنصورة

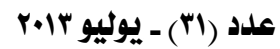




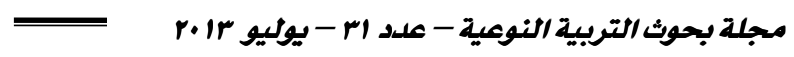

\section{أساليب زخرفة الملابس في المنطقة الشرقية بالمملكة العربية السعودية}

$$
\text { إعداد }
$$

د ـ لينا محمد عبد الله باحيدره **

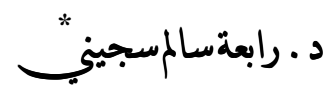

\section{קטito}

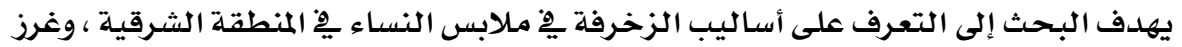

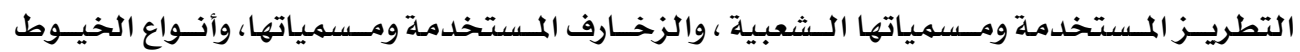

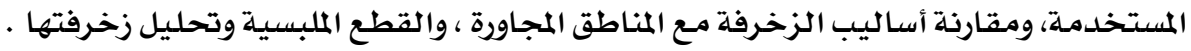

$$
\text { ويتبع البحث المنهج التاريخي الوصفي . }
$$

واستنتتج من البحث أن التطريز الآلي قد استخدم بكثرة يف المنطقة الشرقية خاصدة تطريز

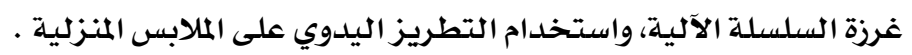

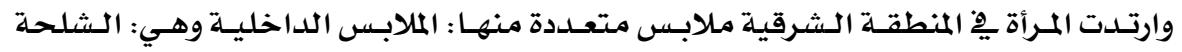

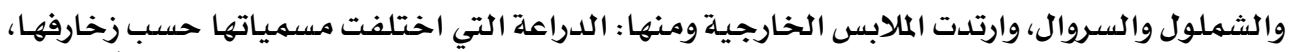

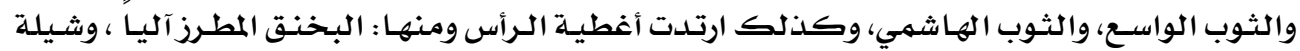
مروجلة ، والبرقع الذهبي. 


\section{أساليب زخرفة الملابس في المنطقة الشرقية بالمهاكة الهربية السهودية}

إعداد

د ـ ـ لينا محمد عبد الله باحيدره

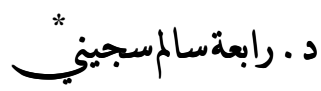

ا - الاقدهة ومشكلة البحث :

تعتبر زخرفة الملابس فناً من الفنون التشكيلية التي تهـدف إلى إعطاء القطع الملبسية قيمـة

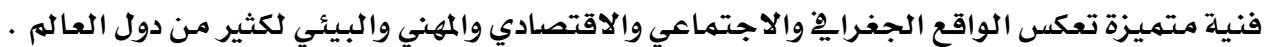
وإذا نظرنا إلى الزخرفة ِِّ الملابس نجد أنها تعكس حياة الشعوب وتراثهم وثقافتهم

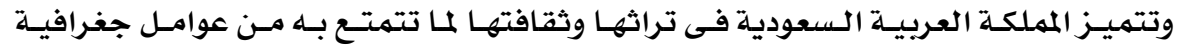

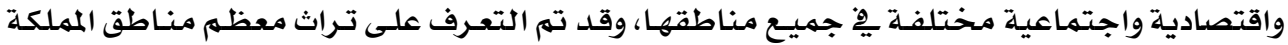

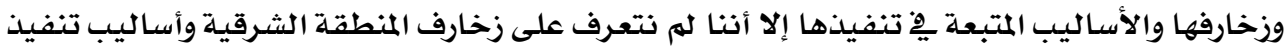
الزخارف فيها.

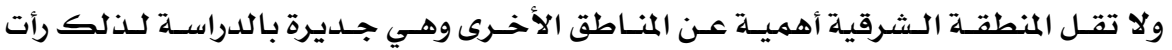

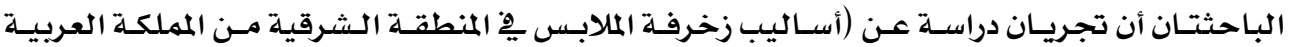

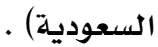

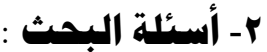

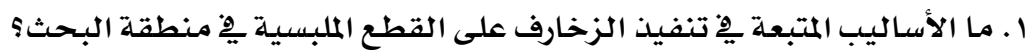

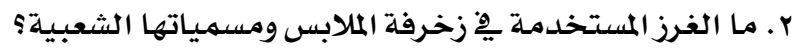

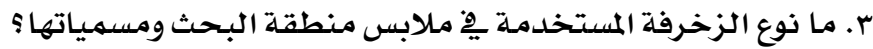

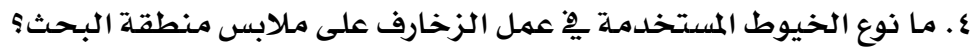

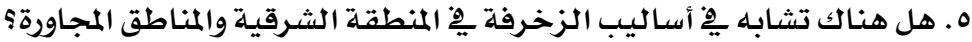

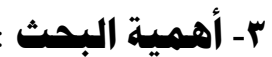

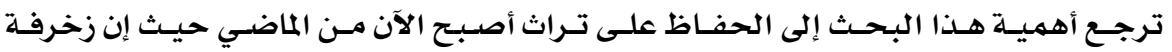

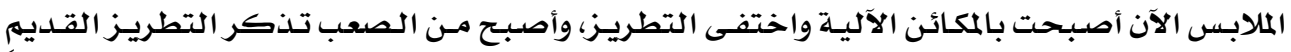

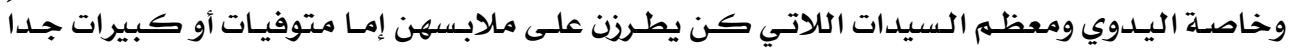

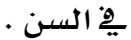

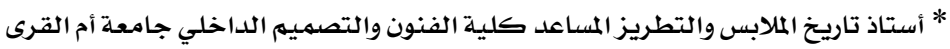

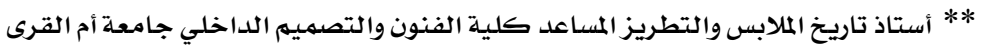


مجلة بحوث التربية النوعية - علد اrr - يوليو rا•r

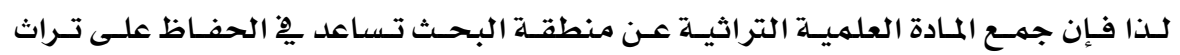

هذه المنطقة.

: ع أهد|ف البهث

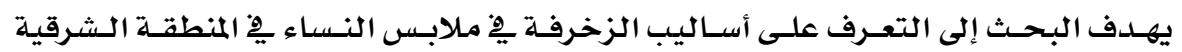

$$
\text { والتعرف على :- }
$$

أ- أساليب الزخرفة يخ القطع الملبسية .

ب- غرز التطريز المستخدمهة ومسمياتها الشعبيـة .

ج- الزخارف المستخدمهة ومسسمياتها.

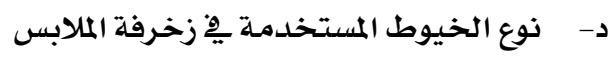

ه- - مقارنة أساليب الزخرفة مـع المناطق المجاورة .

و- القطع الملبسية وتحليل زخرفتها .

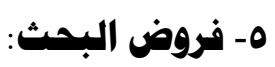

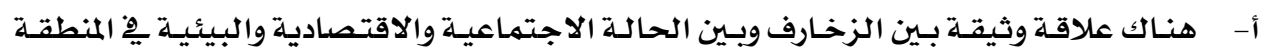

$$
\text { الشرقية. }
$$

ب- ندرة استخدام التطريز اليدوي يِّ ملابس النساء يِ المنطقة الشرقيـة.

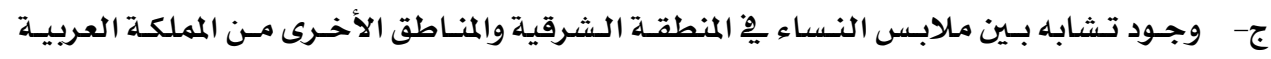

$$
\text { السعودية. }
$$

\section{1- هنهج البحث :}

يتبع البحث المنهج التتاريخي الوصفي ·

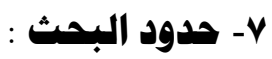

• الحدود البشرية : مجمهوعة من الأفراد من كبار السن الذين كانوا شهود على موضوع الدراسـة

وكانوا يصنعون القطع الملبسيـة .

$$
\begin{aligned}
& \text { • الحدود الزمانية : الحصول على معلومات ترجـع إلى فترة زمنيـة قديمـة . } \\
& \text { • الحلدود الجغرافية : المنطقة الشرقية ( القطيف - الهفوف - الإحساء - الدمام - بقيق) }
\end{aligned}
$$

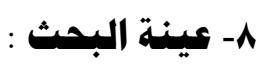

• العينة البشرية : جمـع المعلومـات مـن الأفراد الذين هم أساس المصادر الأولية للبيانات . • العينة المادية : تتمثل يخ القطع الملبسية التي تم الحصول عليها لدراستها وتحليلها. 


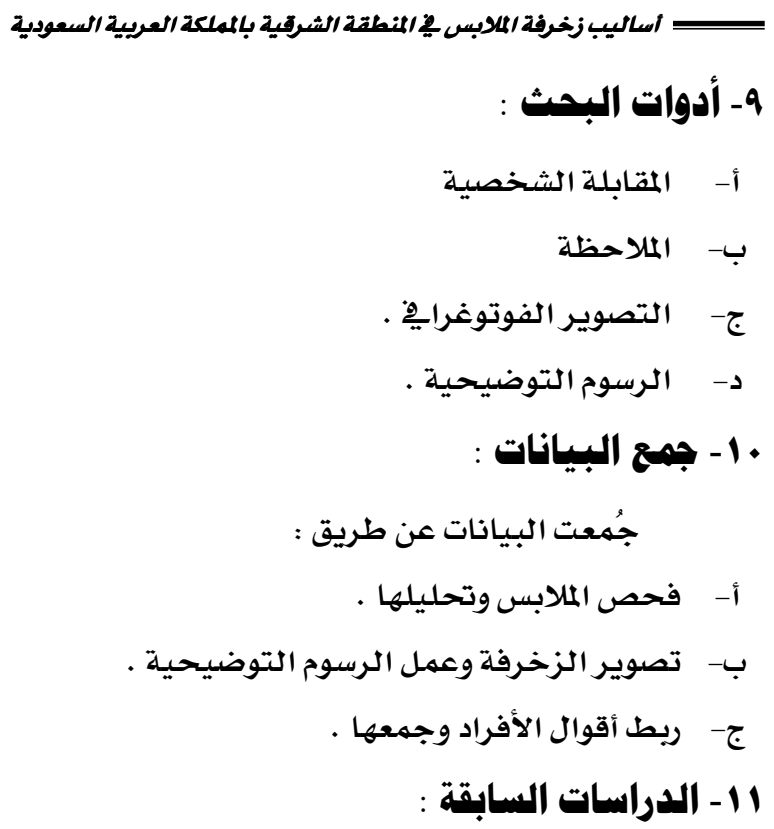

أ- دراسة ( البسام ، 0.rم) ( المابلابس التقليدية الرجالية يِّ المنطقة الشرقية من المملكة العربية

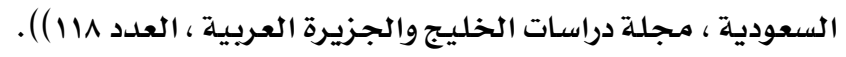

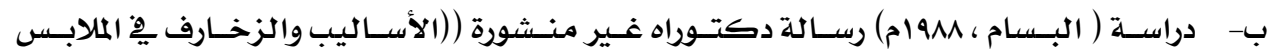

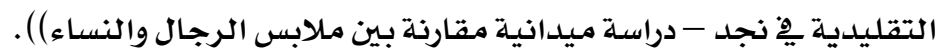

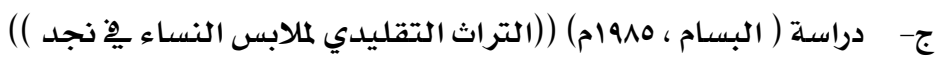

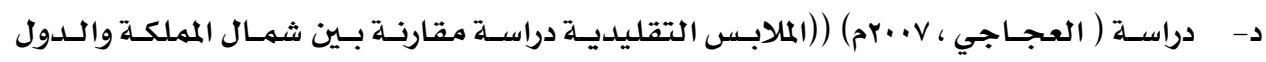

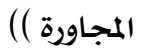

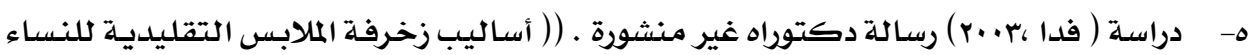

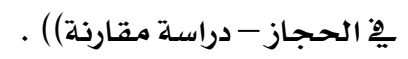

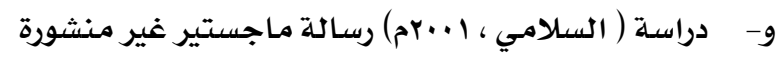

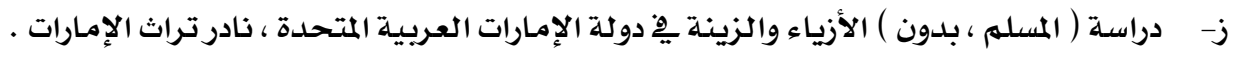

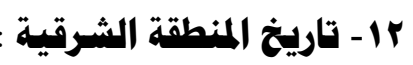

كانت منطقة الدمام مسكونة منـذ القدم إلا أنها اندثرت فترة مـن الزمـن ثم أعـاد الدواسـر

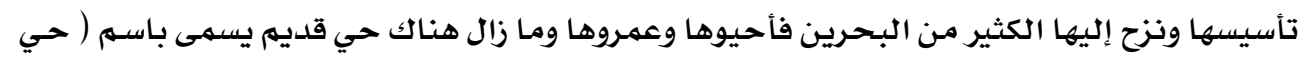

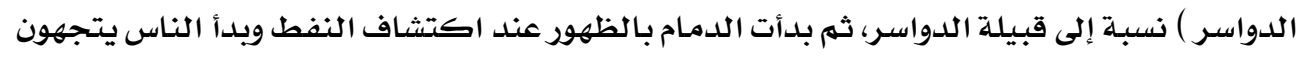

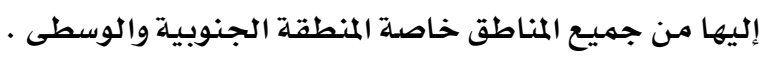

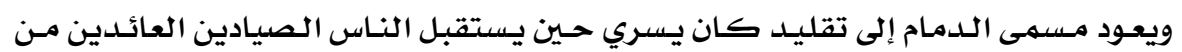

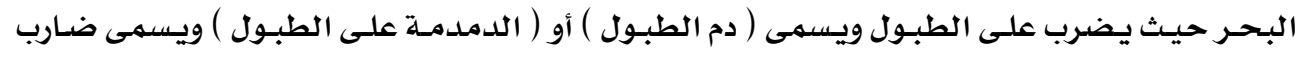




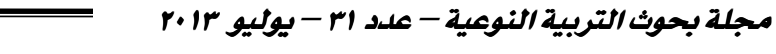

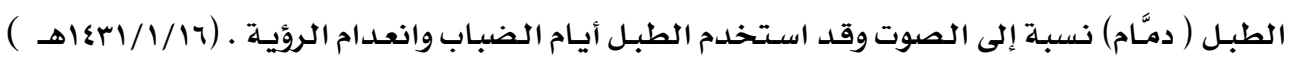
www.alhandasa.net

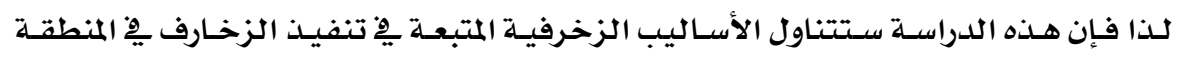

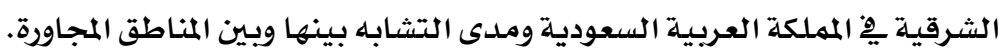

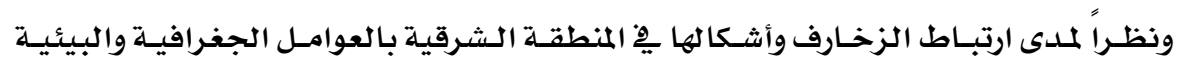
والمهنية فإننا سنلقى الضوء على بعض المعلومات المرتبطة بالزمان وان والمكان:

أ. الموقع :

تقع ِِّْ شرق المملكة العربية السعودية وتطل على الخليج العربي تحسدها الكويـت فِ الشمال

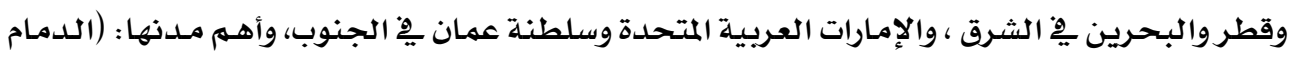

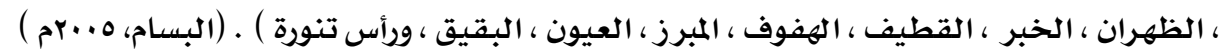

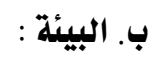

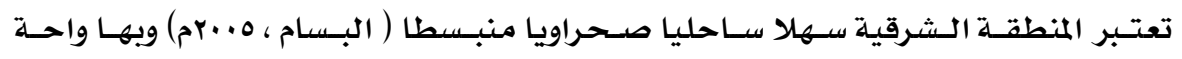

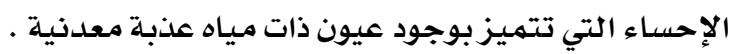

ج. المهن :

ا. اشتهر غالبية سكانها بالزراعة نظراً لوجود واحة الإحساء التي تشتهر بعيونها العذبة ذات المياه

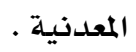

r. عمل بعض سكانها ِِّ التجارة وصيد الأسماك والغوص للبحث عن اللؤلؤ.

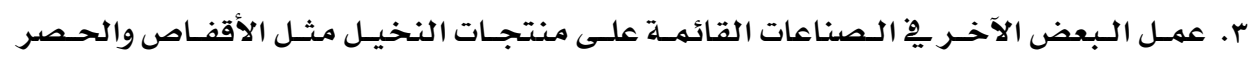

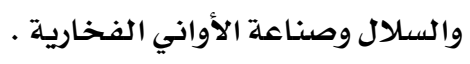

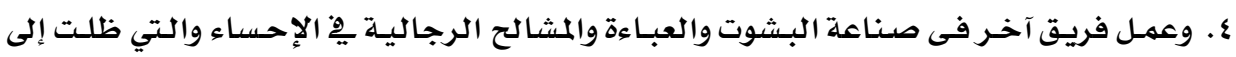

$$
\text { يومنا الحالي. }
$$

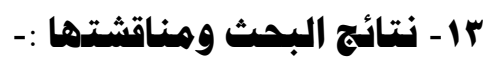

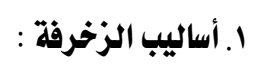

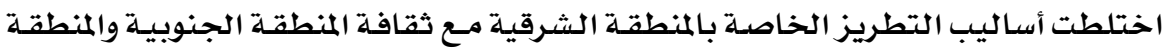

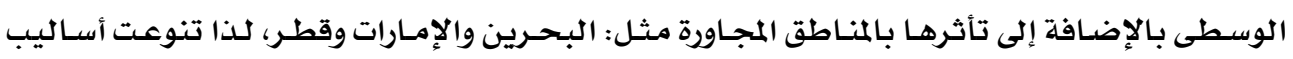

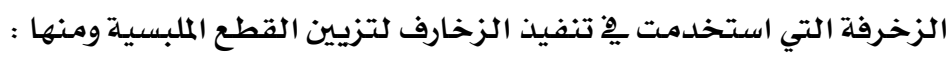

أـ التطريز اليدوي : الترفي اليتخدئ

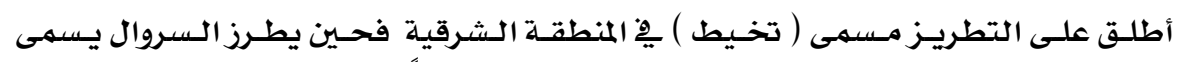

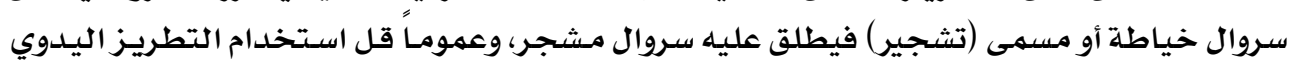




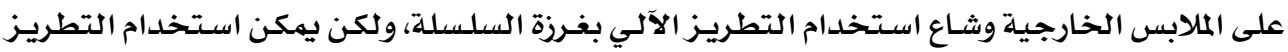

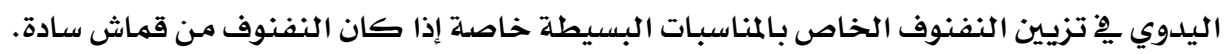
ومـن الفـرز المستخدمة يِّ تطريـز النفنـوف: غـرزة السلسلة ؛ حيـث اسـتخدمت بكثرة سـواء أكانت سلسلة مغلقة أم مفتوحة، وأطلق عليها اسهم: "بخية"

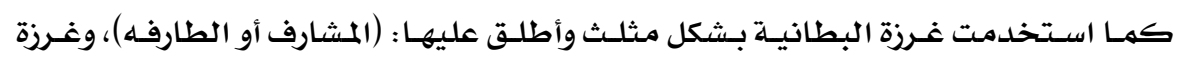

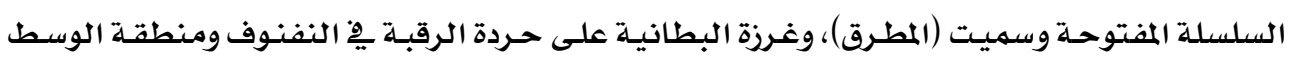
وخط الذيل وقد أخذت هذه الطريقة من قبيلة من الخرمـه وهي قبيلة نازحة من منطقة (الطائف) .

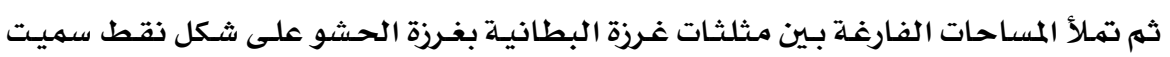

$$
\text { بغرزة (التنقيط) مألمان }
$$

أما إذا كانت الغرزة غرزة سلسلة مفتوحة مـن الطرفين مفردة (غرزة رجل الغـراب) فتسـى :

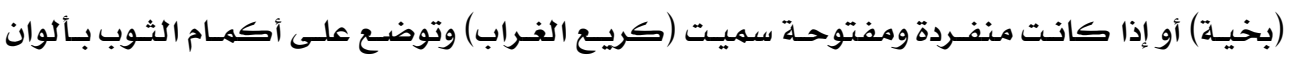

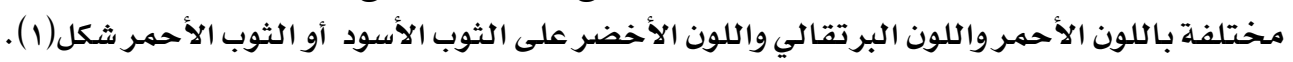

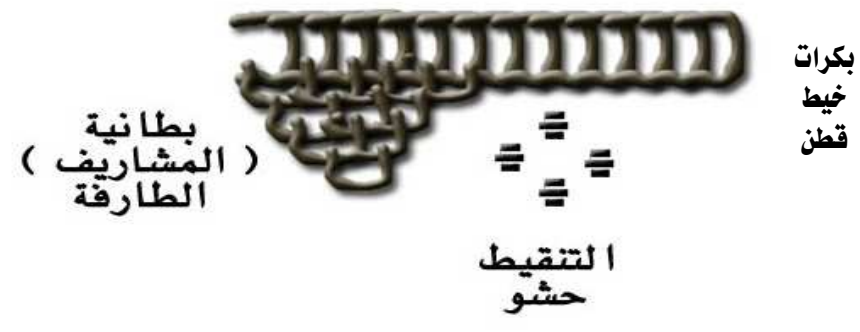

شكل (1)

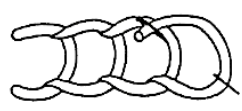

شكل (r)

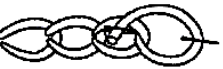

شكل (r)

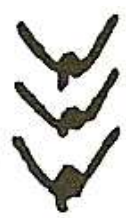

شكل (飞)

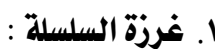

وأطلق عليها اسهم بخية وقد أخذت أشكال مختلفة منها :

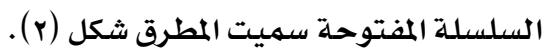

السلسلة المغلقة سميت البخية شكل (r) .

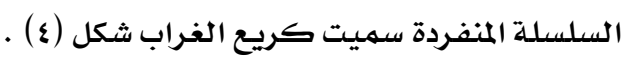




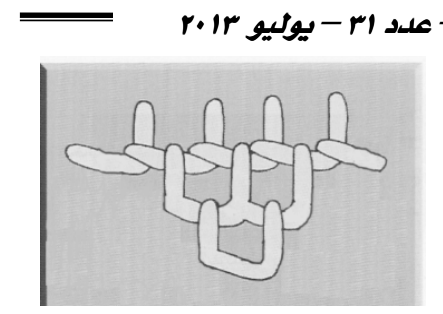

مجلة بحوث التربية النوعية-

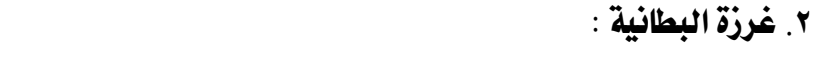

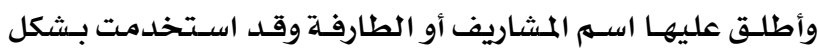

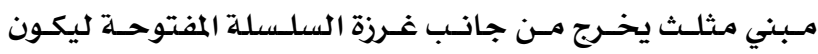

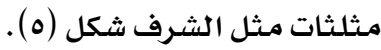

شكل (0)

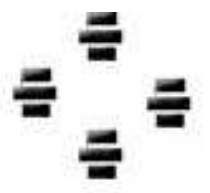

وأ. غرزة الحشو :

شكل (7)

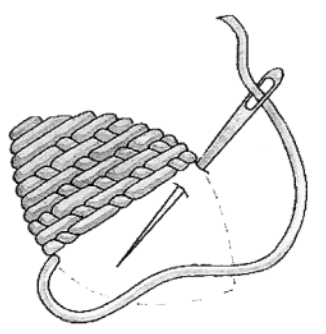

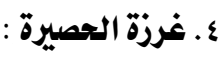

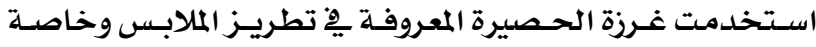

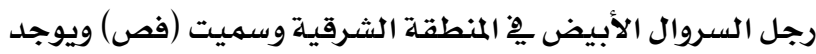

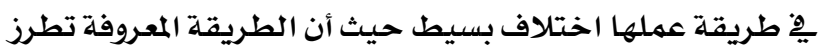

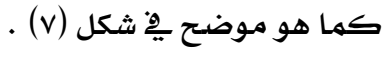

(v) شكل

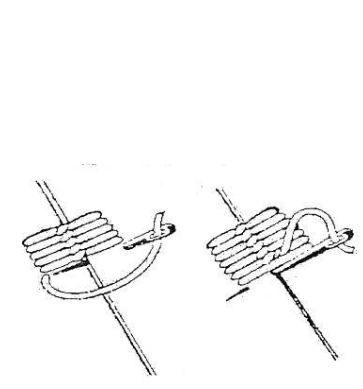

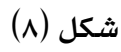

أمـا الطريقـة التقليديـة لغـرزة الحـصيرة الستي اسـتخدمت فِ

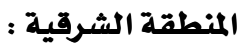

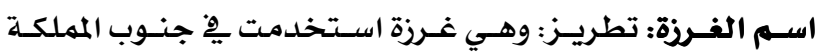

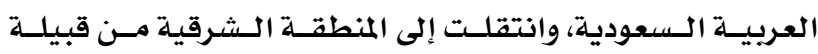

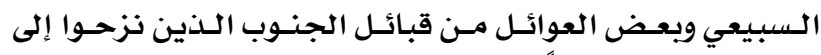

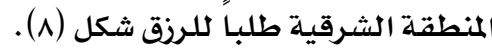
أماكن استخدامها : الفرث والمخدات فائدتها: تستخدم فِ الملابس: نوع الخيط المستخدم: كوتنبر ليـة 

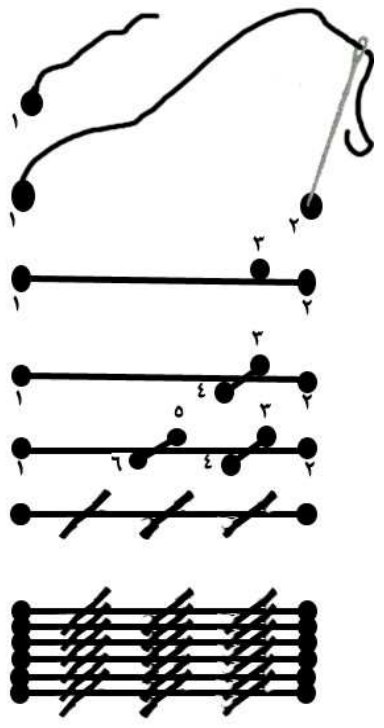

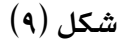

وطريقة تطريزها كالتالي شكل (ه) :

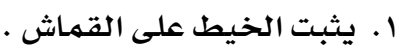

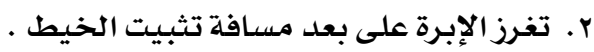

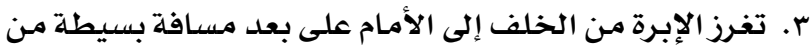

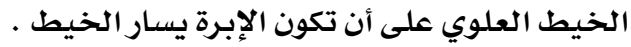

ع. تغرز الإبرة بعد مسافة بسيطة جدا عن الخيط.

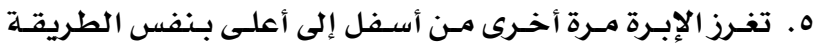

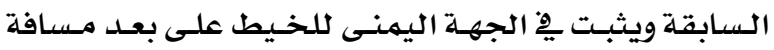

كما سبق .

T. تكرر الصفوف بـفس الطريقـة السابقة على أن يكون تثبيت

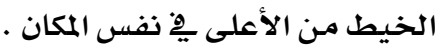

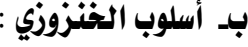

يزين طرف السروال بغـرزتطريز مختلفـة مكونة مـن زخرفة مميـزة أطلق عليها يِّ المنطقسة

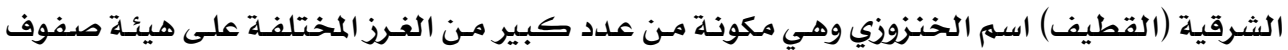

متراصدة شكل (.1) وصورة (1).

طريقة عملها :

ا ـ يبطن رجل السروال ببطانـة ( حاشية ) سـوداء اللون مـن وجـه القهماش حسب الغـرض المطلوب

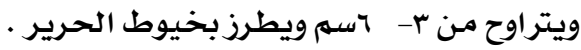

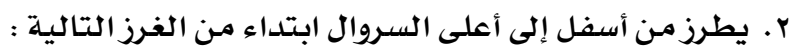

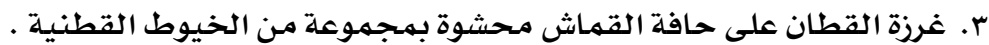

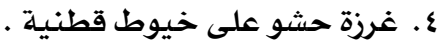

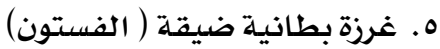

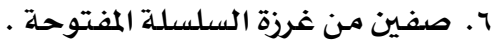

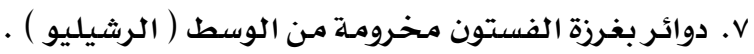

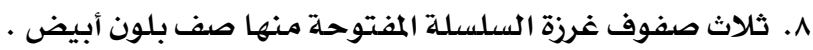

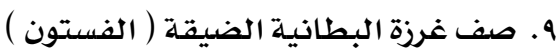

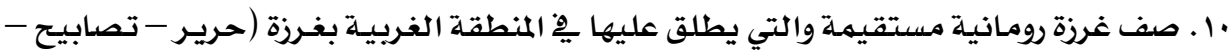

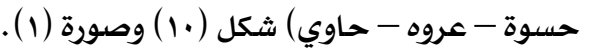




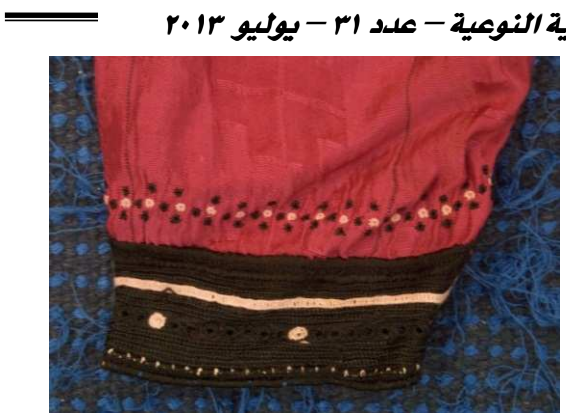

صورة (1)

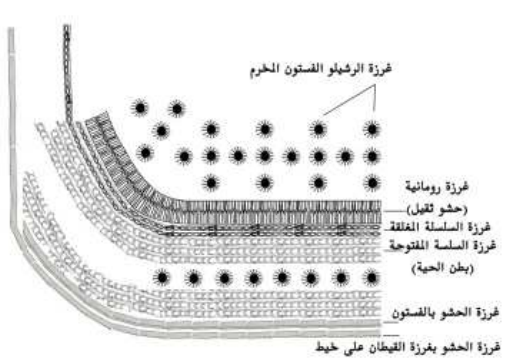

شكل (1.)

ج- الكروشيه :

يزين نساء المنطقة الشرقية أطراف السروال بأسلوب آخر غير التطريزوهو أسلوب الكروشيه

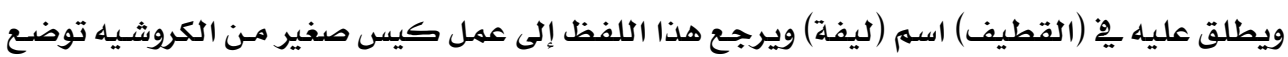
فيه الصابونة لدعك وتنظيف الجسم وهي معروفة باسم ليفة صورة (r وrr) .

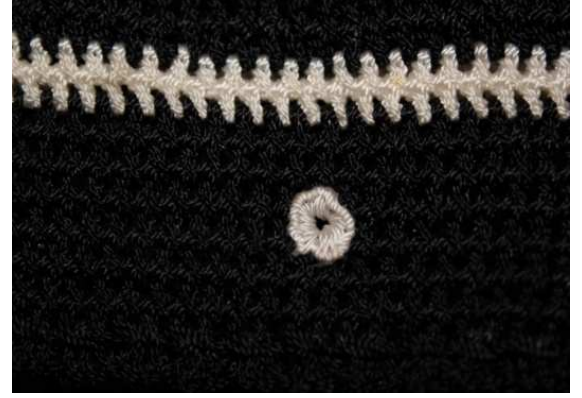

صورة (r)

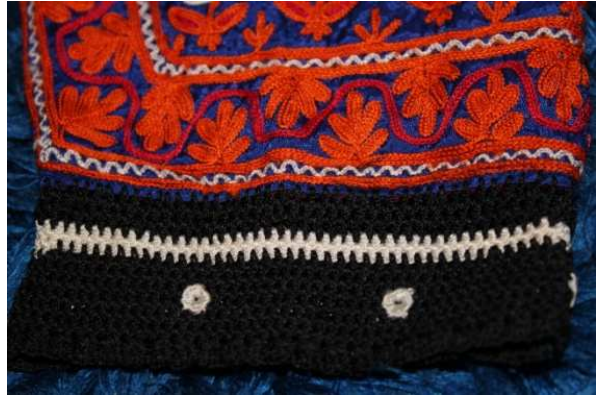

صورة (r) (r) (1) (1) (1)

\section{دـ شفل الكورارة: - د}

وهو تطريز بخيوط مجدولـة مـن خيوط القطن أو الشرائط المجدولـة بخيوط الحرير وهي

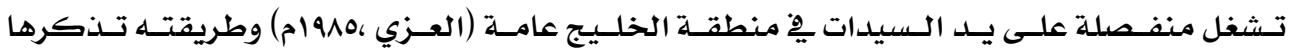

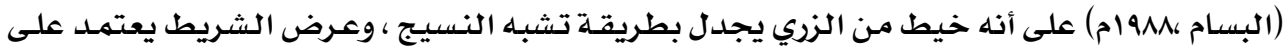

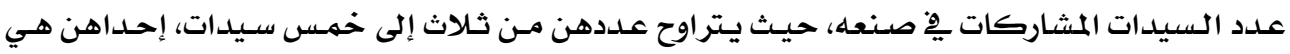

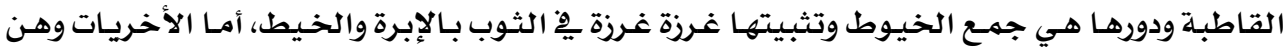

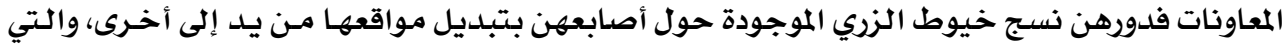

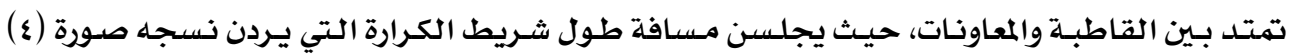




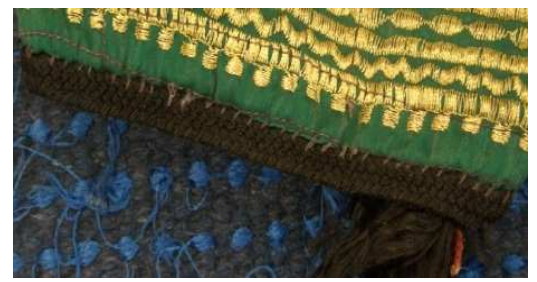

صورة (0)

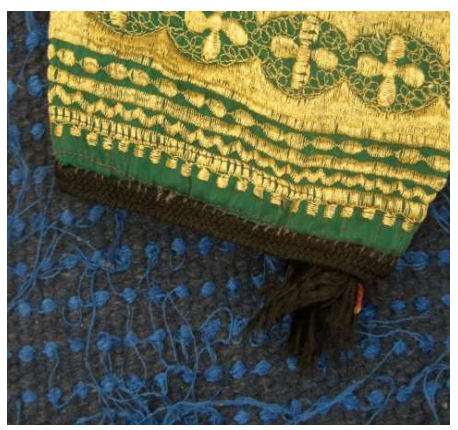

صورة (飞)

هـ البادلة ( التلي ) :

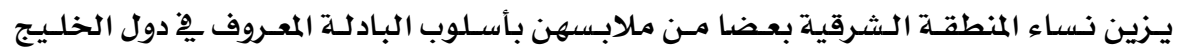

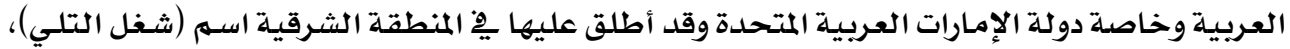

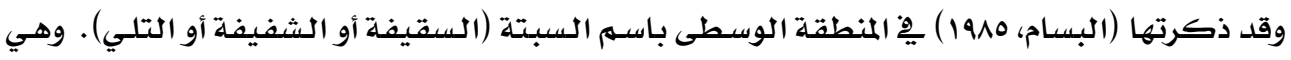

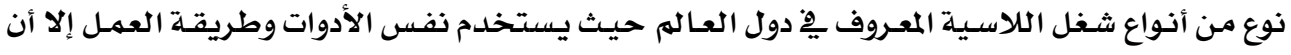

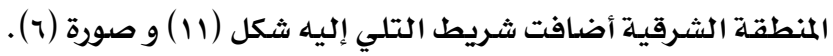
أولاً: أدواته :

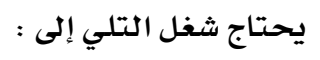

أ- أداة صنـع التلي : وتسمى يِّ المنطقة الشرقية بالكيرخانه وتتكون من جزئين :

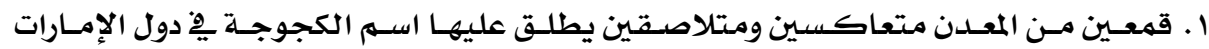

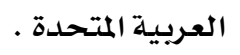

r. المخدة : وهي وسادة أسطوانية الشكل من القطن التحن تلف عليها الخيوط .

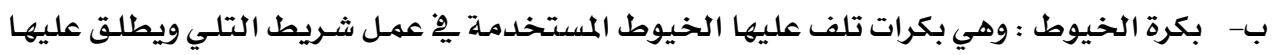

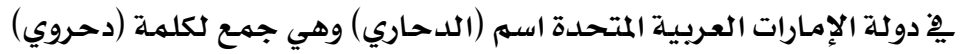

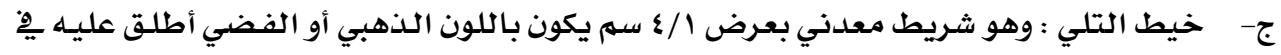

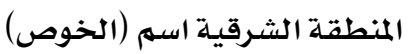

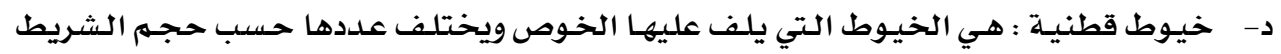
المراد صنعها وأقلها ستة خيوط ويطلق على الخيوط الخيوط يِّ المنطقة الشرقية اسهم (الهلدبة).

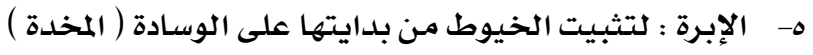

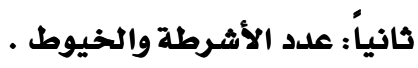
ا. البتـول : هـو أقـل الأثـرطة حيـث يـتم وضـع ب بكـرات مـن الخيـوط القطنيـة وبكـرة واحـــة مـن 


\section{r. البادلة ولها أنواع مختلفة}

أ- الصغيرة : يستخلدم لصنعها ^ بكرات من الخيوط القطنية وبكرتين من الخوص.

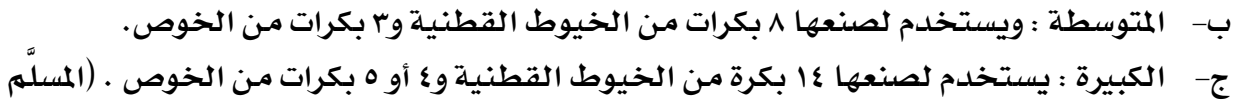

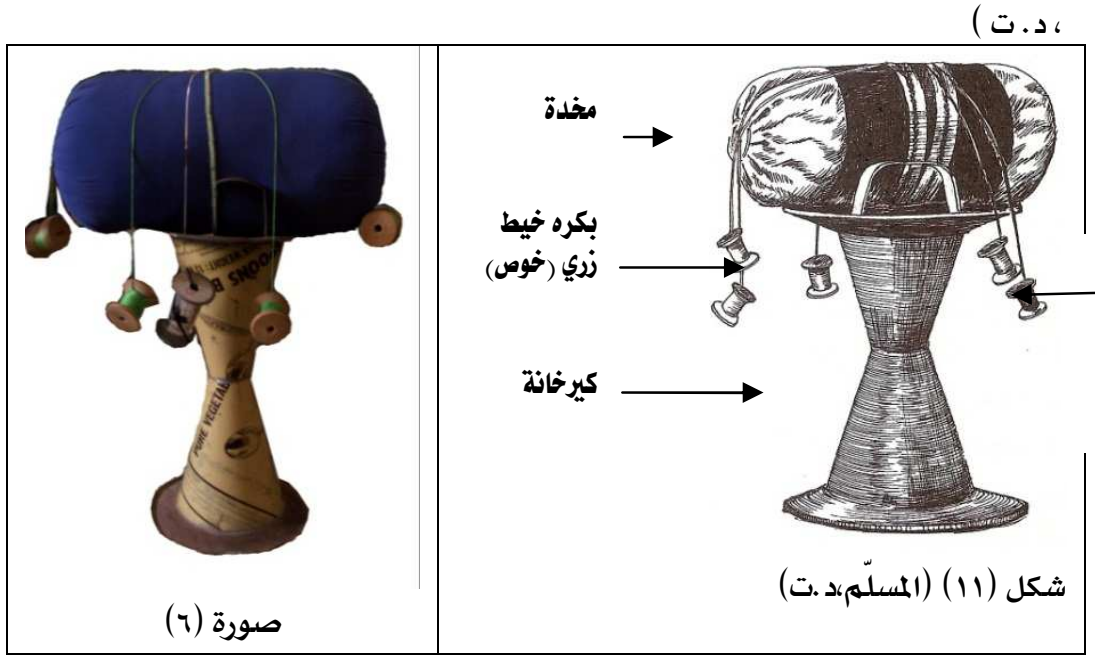

وـ شفل التلي في المنطقة الشرقية (البتول) :

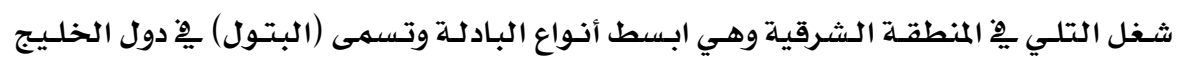
العربي وتتكون من ستة خيوط قطنية تسهى (أهداب) وخيط واحد من المعدن يسهى (الخوص) تذكر

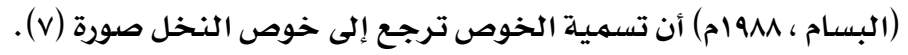

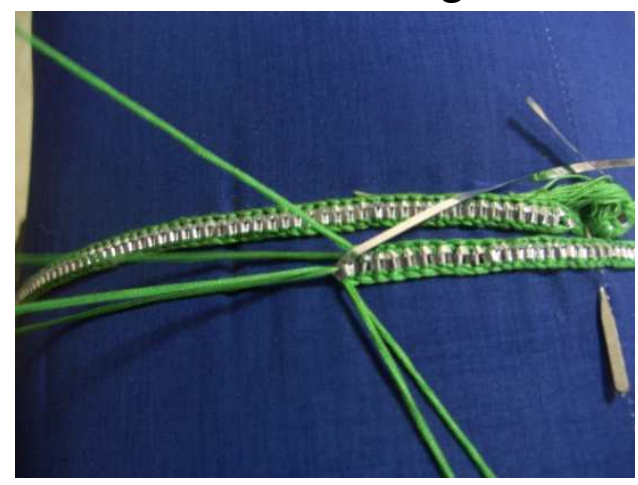

(v) صورة (v) 


$$
\text { طريقة عمل البادله (البتول) : }
$$

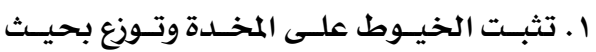

تكـــون: خــيطين قطنـــيـين علـــى الـــيمـين،

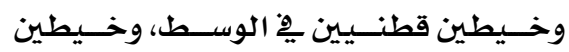

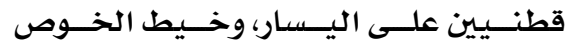

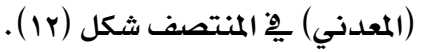

شكل (ir)

$$
\begin{aligned}
& \text { r ب يرفع الخيطان القطنيان من الجهة اليمنى، }
\end{aligned}
$$

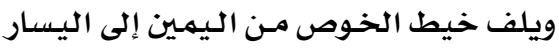

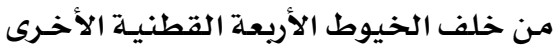

$$
\begin{aligned}
& \text { شكل (r) من خلف الحي }
\end{aligned}
$$

شكل (ir)

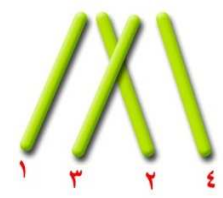

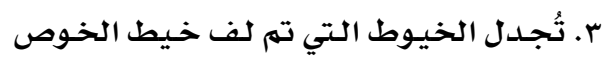

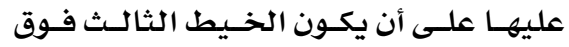

$$
\begin{aligned}
& \text { الخيط الثاني شكل (ع) ). }
\end{aligned}
$$

شكل (1)

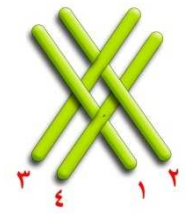

ع ـ ثــم تُجــــل بـاقي الخيـوط علــى أن يكــون

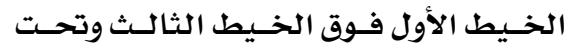

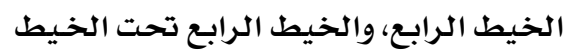
الثاني وفوق الخيط الأول شكل (10).

شكل (10)

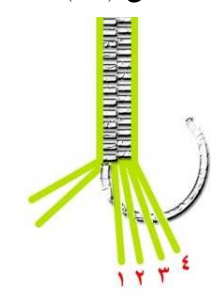

$$
\text { ه ـ يسـحب الخيطان القطنيان من جهـة اليسـار }
$$

شكل (17) 


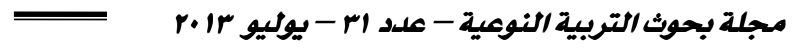

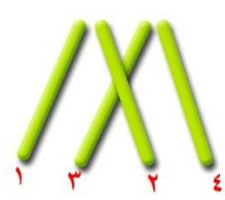

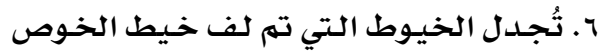

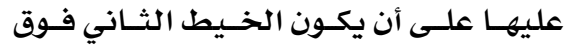

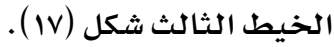

(IV) شكل

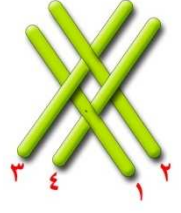

$$
\begin{aligned}
& \text { V . ثــم تُجــــل بـاقي الخيـوط علسى أن يكـون }
\end{aligned}
$$

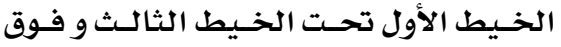

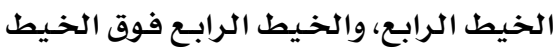

$$
\begin{aligned}
& \text { الثاني وتحت الخيط الأول شكل (1) ). }
\end{aligned}
$$

شكل (1^)

r.الزخارف المستخدمة ومسمياتها في القطيف في حارة التوبي .

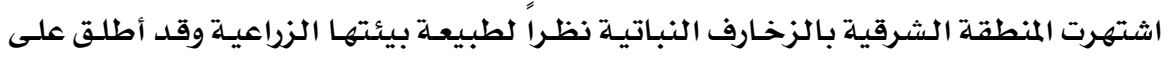

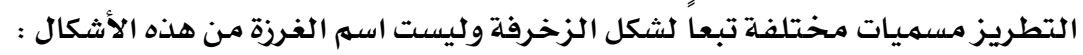

أ- التطريز على السروال أبو بطانـة بغـرزة السلسلـة بـالخيوط المعدنيـة بأشـكال مختلفــة أطلق عليها

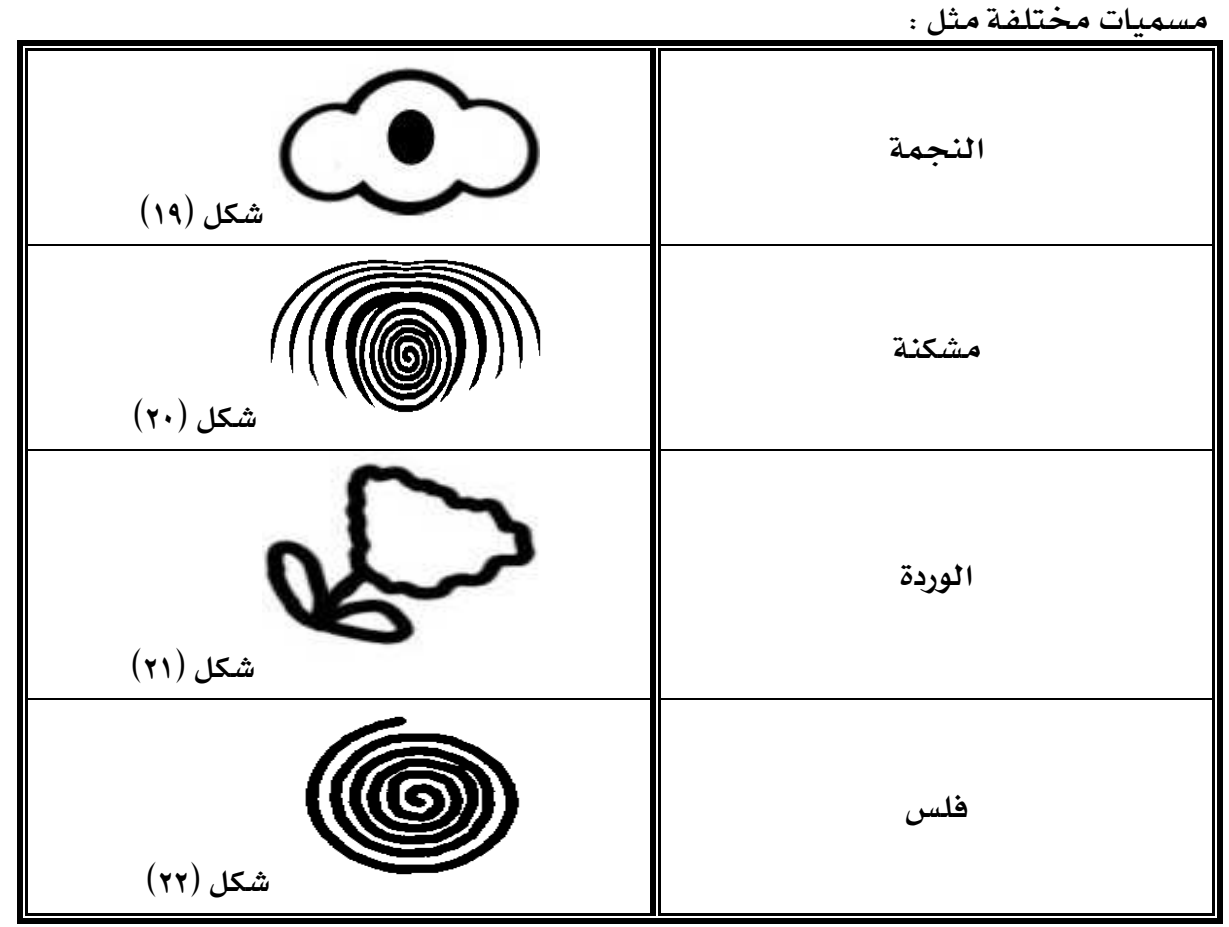


ب- التطريز على السروال بالخيوط الملونة وأطلق عليه اسهم المشجر صورة (^) و صورة (ه) . .

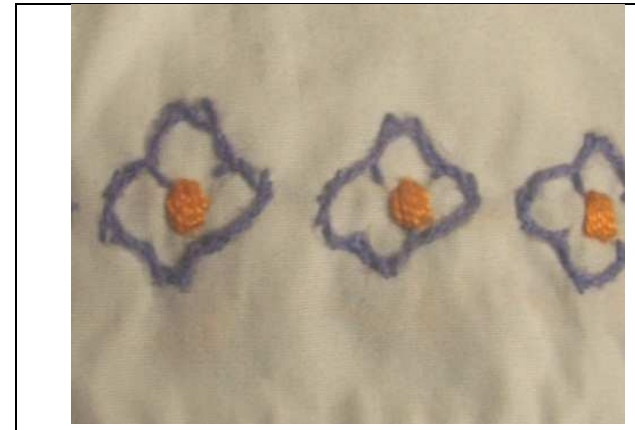

صورة (a) (a) (1) (1)

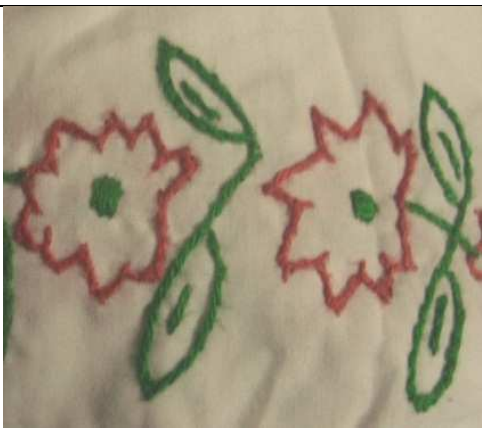

صورة (^)

ج- التطريز على السروال الأبيض بالخيوط الملونة بأشكال مختلفة منها :

$$
\text { ا }
$$

يطـرز الـشكل المعــين بغـرزة السـلـسلة ، والـشكليين المستطيلين المتقــاطعين يطـرزين بغـرزة

الحصيرة صورة (·1) و صورة (11)

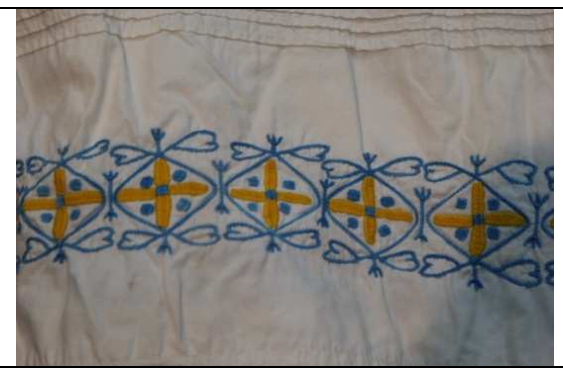

صورة (II)

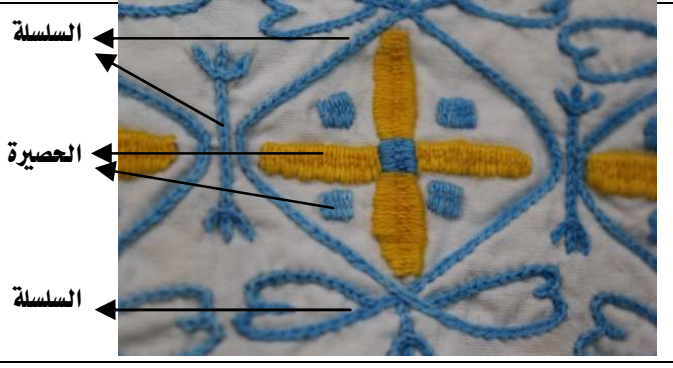

صورة (.)

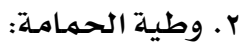

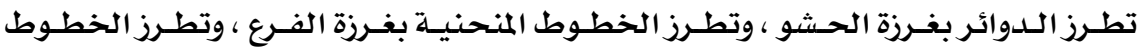

المتوازية بغرزة الفرع صورة (r ) .

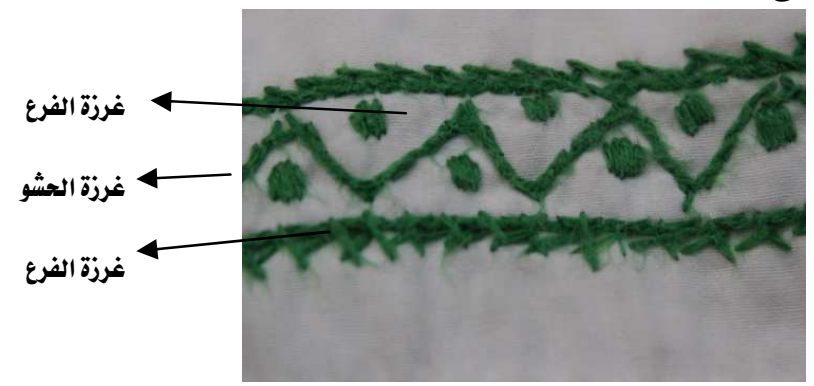

صورة (ז) 
مجلة بحوث التربية النوعية - علد اrr - يوليو rا•r

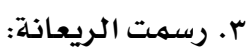

تطرز الدوائر الصغيرة بغرزة الحشو، وتطرز الأوراق بغرزة الحشو ، ثم تطرز الوردة والأغصان

بغرزة الفرع صورة (ri) .

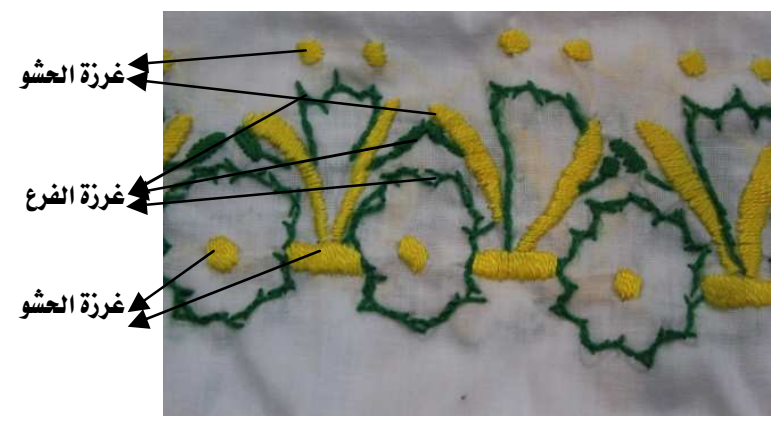

صورة (iv)

ع. الطارة :

تطرز بغرزة الآجور صورة (ع ).

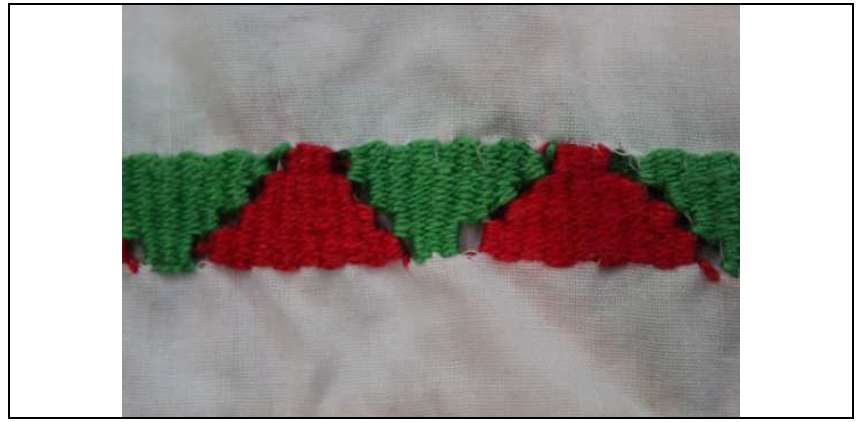

صورة (1 (1) - (1)

0. المحيط:

تطرز بغرزة الحشو صورة (10).

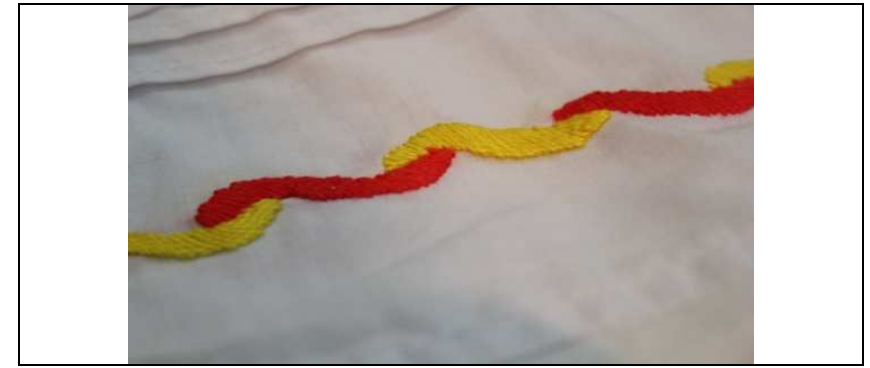

صورة (10) 
تطرز الوردة بغرزة الفرع ، وتطرز الورقة بغرزة الحشو صورة (1 ).

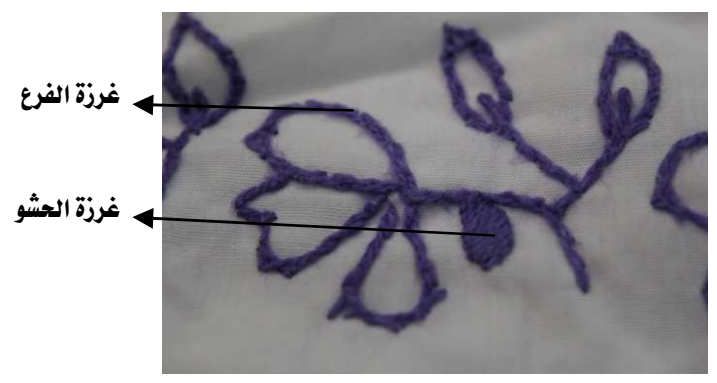

صورة (17) (17)

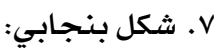

تطرز بغرزة الفرع صورة (IV) وشكل (rr) .
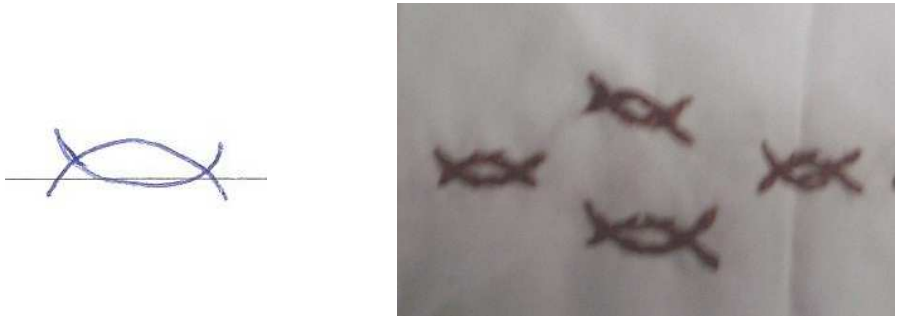

شكل (rr)

صورة (IV) (1V)

^. الزخرفـة علـى الســروال علـى شـكل أسـهمه بغـرزة الفـرع وسهـي قـرن العجـل ثـم توضــع زخرفـة هندسيـة على الحـافة بشكل متعـدد وتسهى نثرة وأي بـروز يْ التطريز يطلق عليها نثرة شكل

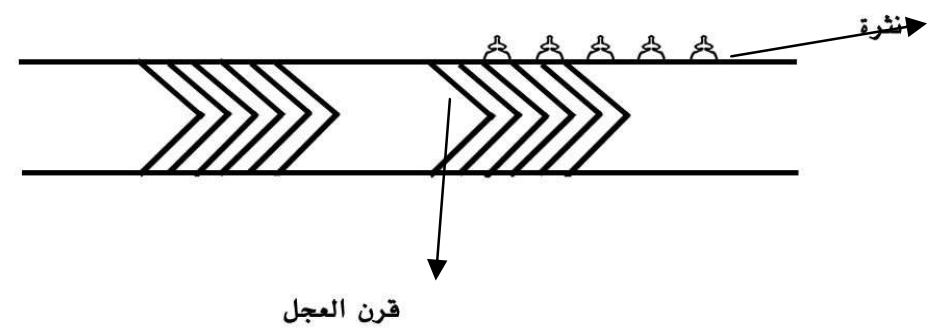

شكل (r) 


\section{†. ملابس النساء في المنطقة الشرقية:}

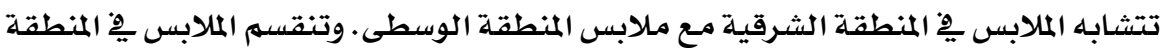

$$
\begin{aligned}
& \text { الشرقية إلى قسمين ملابس داخلية وملابس خارجية . } \\
& \text { أولاً : الملابس الداخلية : }
\end{aligned}
$$

يعتبر السروال من أهم القطع الملبسية عند المرأة يِّ المنطقة الشرقية .

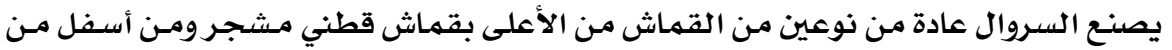

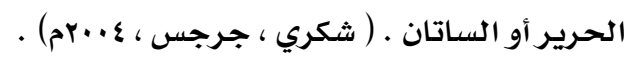

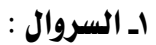

ارتدت النساء يِّ المنطقة الشرقية تحت الثياب سـراويل مختلفـة الأشكال مـن حيث التطريز

والتفصيل منها :

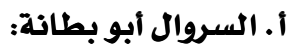

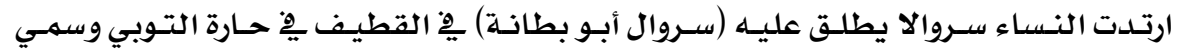

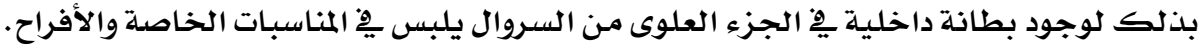

$$
\text { طريقة تفصيله : }
$$

يتكون السروال من ثلاثة أجزاء رئيسة:

$$
\begin{aligned}
& \text { • الجزء الأعلى من السـروال }
\end{aligned}
$$

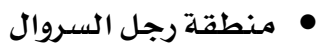

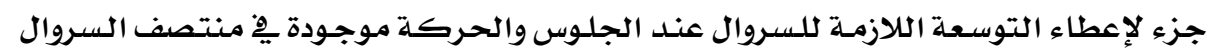

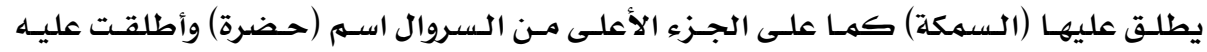

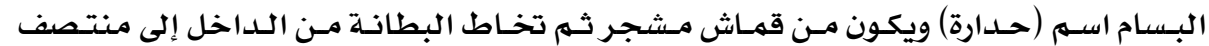

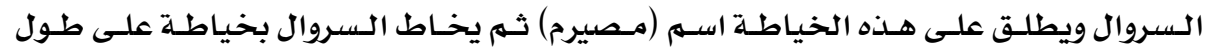

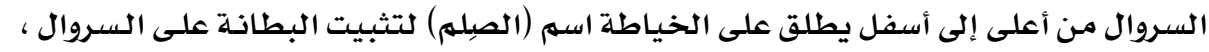

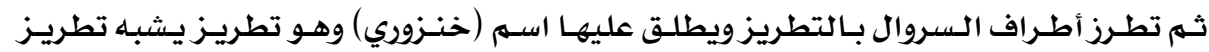

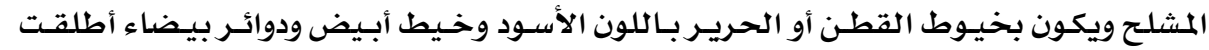

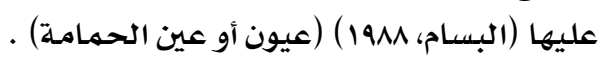

أماكن التطريز:

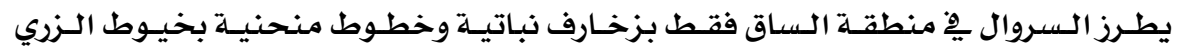

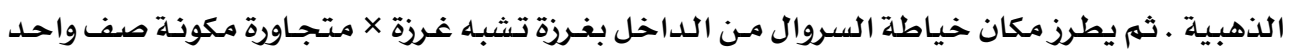

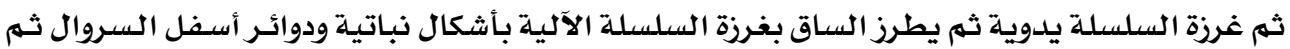

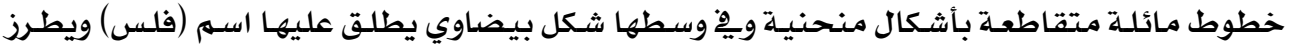

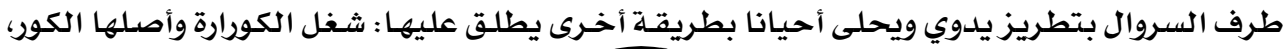




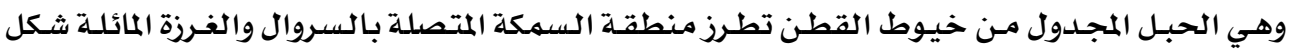

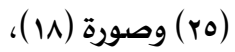

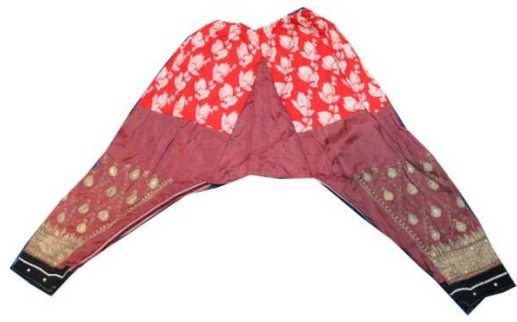

صورة (1)

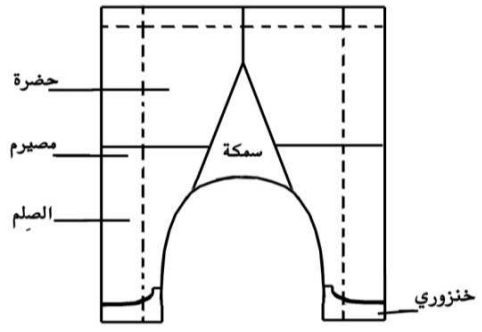

شكل (ro)

ب. السروال المشجر :

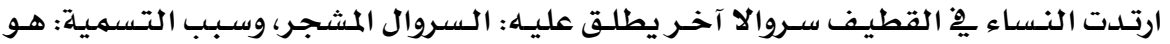

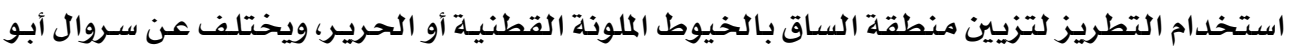

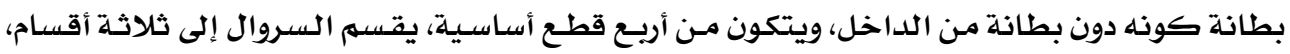

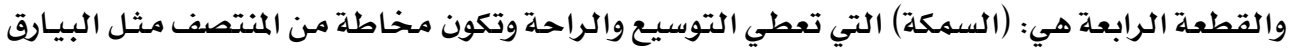

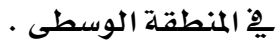
أماكن التطريز:

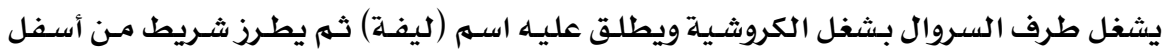

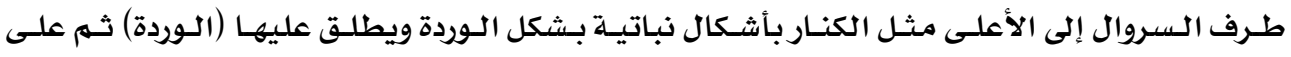

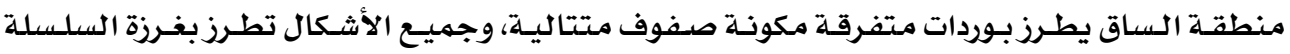
بخيوط ملونة باللون البرتقالي والأبيض والأحمر بخيوط قطنية وحريريـة شكل (جrية ) و صورة (19) . التطريز بغرزة السلسلة الالية . بهيوف يطلق على التطريز يِ المنطقة الشرقية اسمى (خوار أو دكة) شكل (rV).

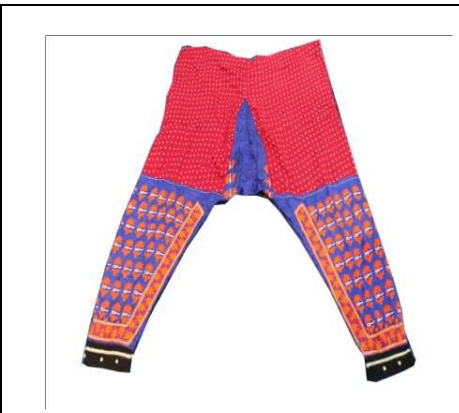

صورة (19) (19)

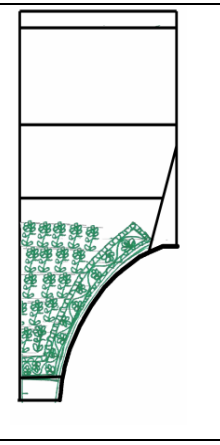

شكل (rv)

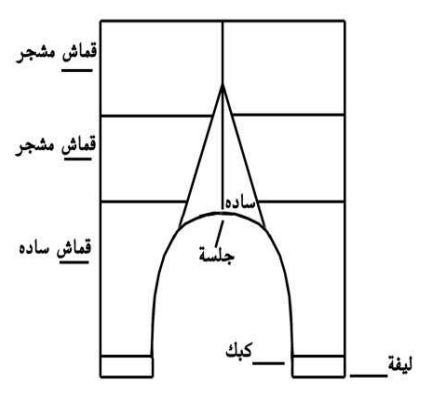

شكل (r) 
ج- السروال (خياطة):

ارتدت السروال (خياطة) نساء المنطقة الشرقية سمي بـلك لكثرة القطـع المخاطة، ويلبس

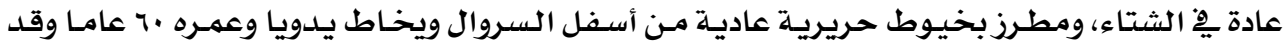

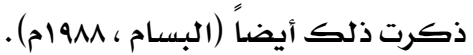

طريقة تفصيله:

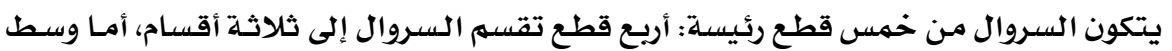

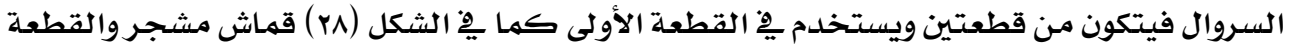

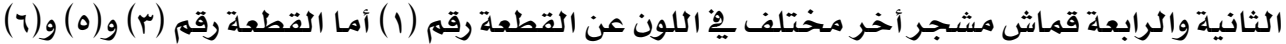
فهمن قماش سادة . أماكن التطريز: لا يوجد تطريز على ساق السروال كما يِّ سـروال (أبو بطانة) والسروال المشجر، وإنها يطرز

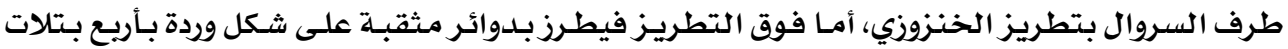

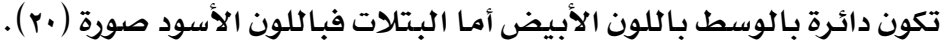

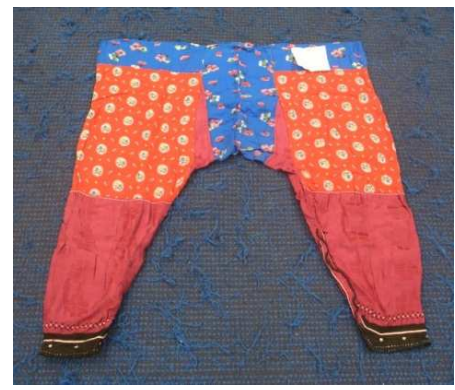

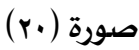

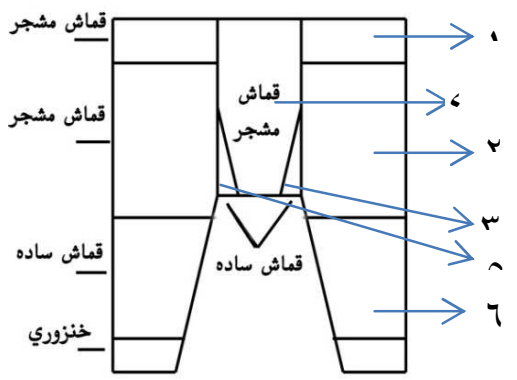

شكل (r^)

د. سروال خياطة يدوي :

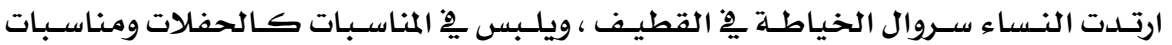

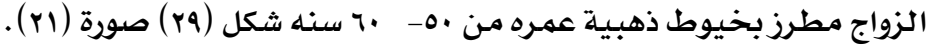

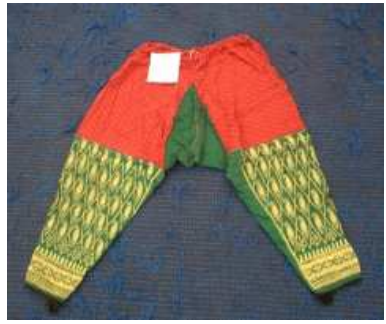

صورة (r) صو

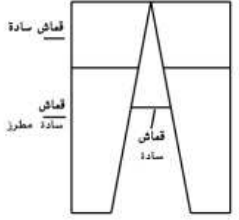

شكل (rq) 
يلبس بِ الشتاء ومطرز بخيوط ذهبية ويخاط يدويا ، وعمره •ج عاما شكل (·r) صورة (rr).

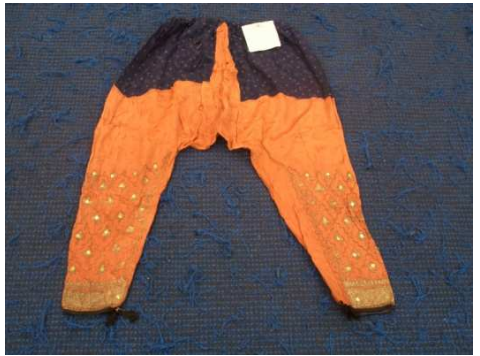

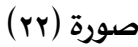

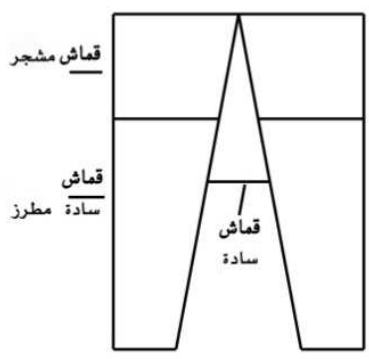

شكل (r) (r) (n)

و- سروال الدار:

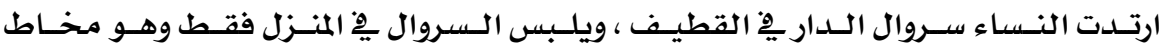

بالماكينة اليدوية ولا يطرز صورة (r) ).

\section{طريقة تفصيلة:}

يتكون من ثلاث قطع رئيسية القطعة رقم (1) و (Y) تفصل السروال إلى قسمين، أمـا القطعـة

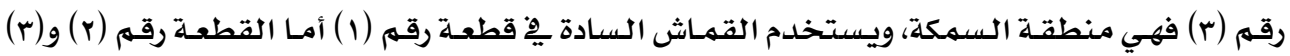

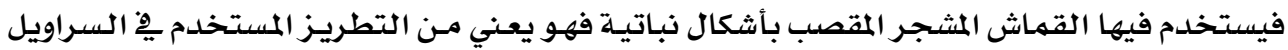

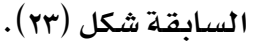

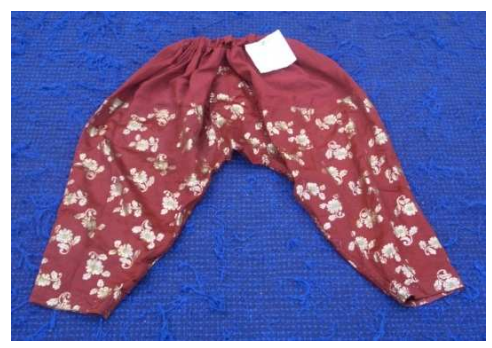

صورة (rr)

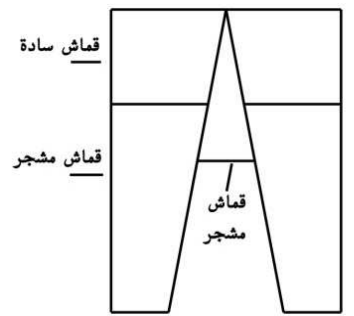

شكل (r) (r)

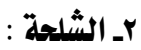

ما تلبسـه المرأة على الجسلد مباشرة وهو يغطي جسهم المرأة مـن الأعلى إلى القدم وتتكون مـن

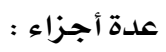

أ- الحماليات: وهي ما تثبت على كتف المرأة وتكثف عن الذراعين .

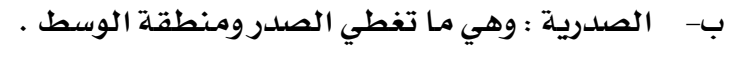


مجلة بحوث التربية النوعية - علد اسم - يوليو rامبr

ج- الـصياصـة : وهـو الجـزء السـفلي مـن الـشلحة ويبــأ مـن الوسـط إلى القـــم وهـو مـذموم مـن

$$
\text { الوسط وواسـع. }
$$

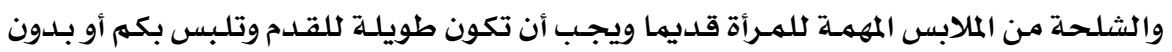

كم شكل (1) . (1).

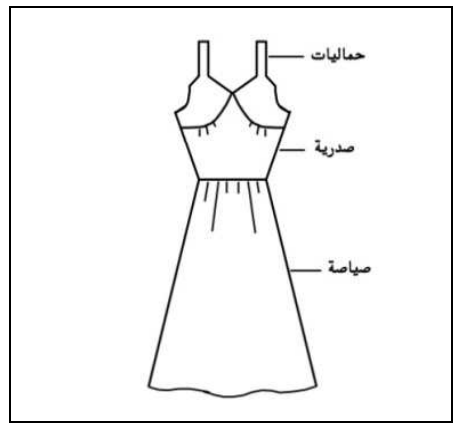

شكل (1)

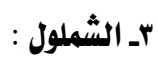

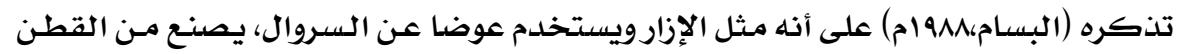

$$
\text { ويطرز أطرافه ويزين. }
$$

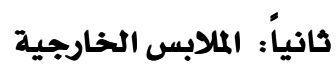

ارتدت النسـاء الدراعة التي تشبـه كثير دراعة النسـاء يِّ المنطقة الوسطى واختلف مسسماها

حسب طريقة التطريز المستخدم وشكله فمنها:

اــ دراعة (أم خُمَاس)

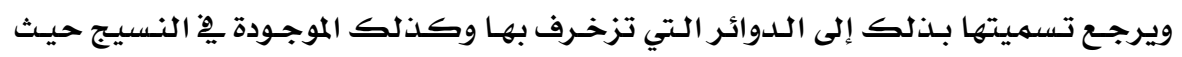

يستخدم النسيـج المشجر بأشكال الدوائر، وهذا الثوب مأخوذ من دولية الإمارات العربية المتحدة.

طريقة تفمسيلها:

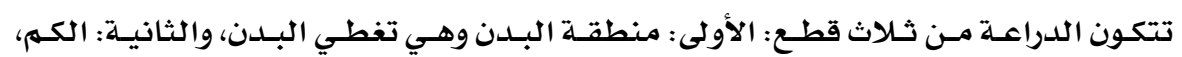

والثالثة: قطعة مثلثة صغيرة تركب أسفل الكم لإعطاء الراحة تسهى (مدخلة) ، وبها جيب ِِ2 الجهـة اليمنى من خط جنب الدراعة شكل (اب) .

\section{أماكن التطريز:}

تطرز الدراعة عند محيط الرقبـة ومحيط الأسورة ٌِِ طرف الكمم بخطوط مـن غرزة السلسلة

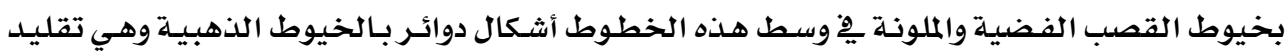
لشخل التلي أو الشخل الذي يطلق عليه شغل (البـادلة) يْ الامارات والبحرين صورة (rr ). 


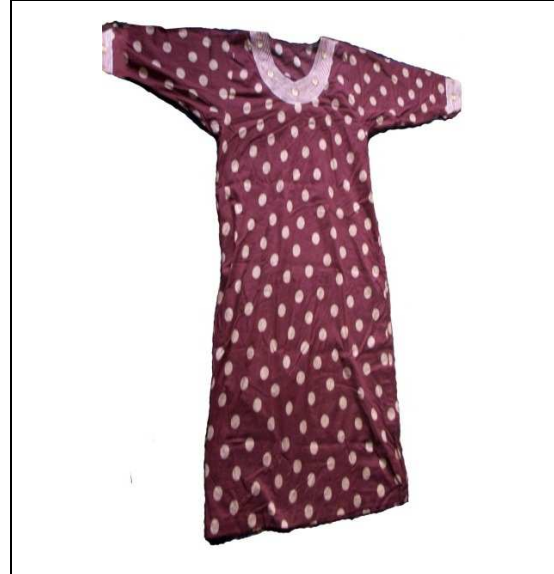

صورة (rr) (r) (1) (n)

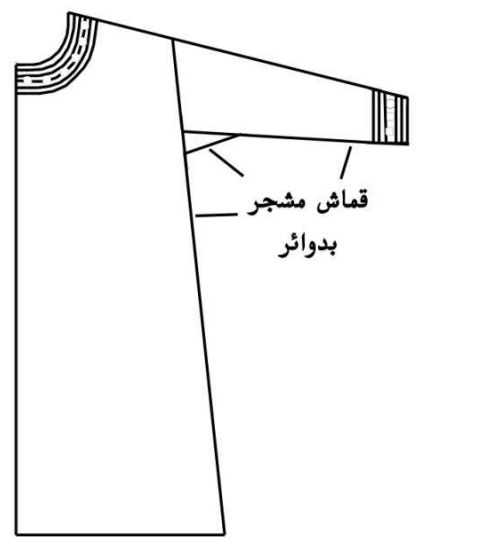

شكل (rr)

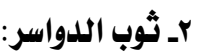

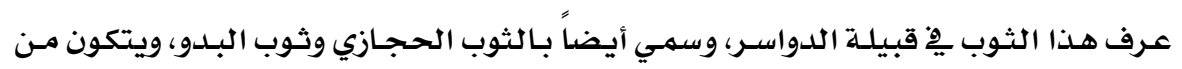

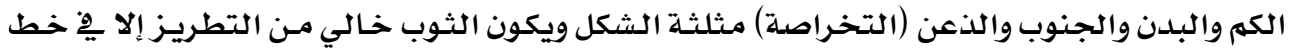

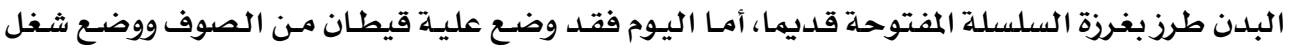

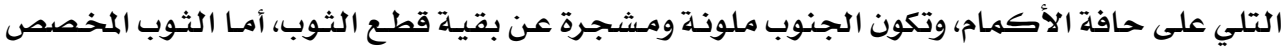

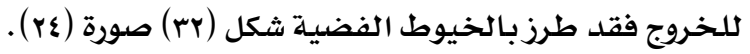

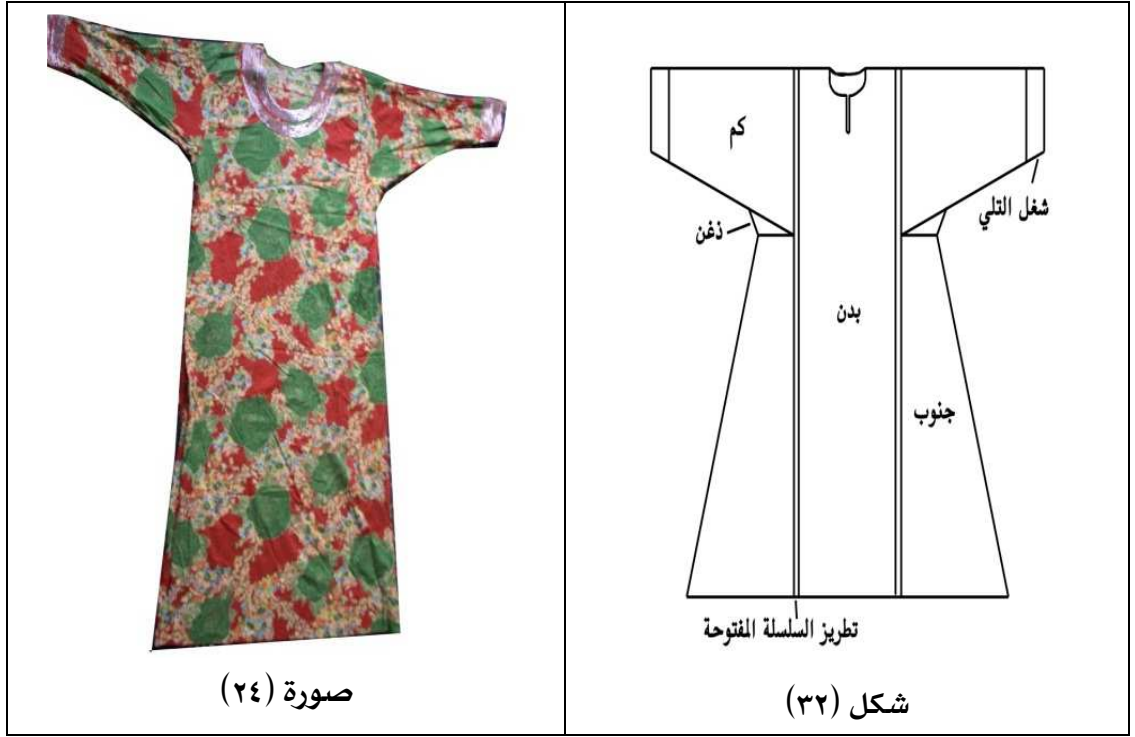




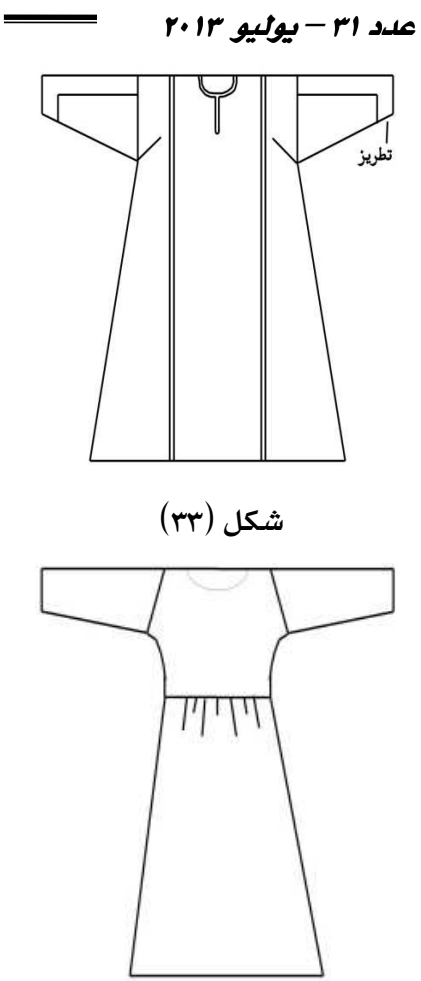

شكل (r々)

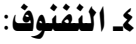

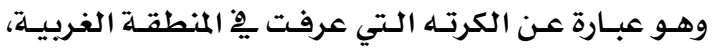

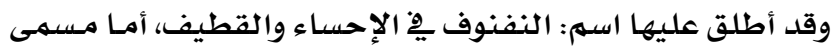

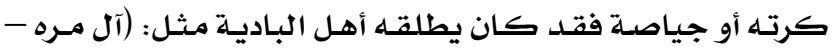

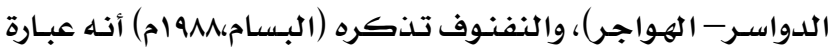

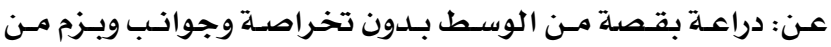

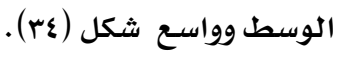

وهناك مسميات للثياب تعتمد على زخرفة الثوب مثل :

• ثوب رش المطر: يصنع من قماش مشجر بلدوائر صغيرة جداً.

• ثوب الزري: يصنع من خيوط القصب.

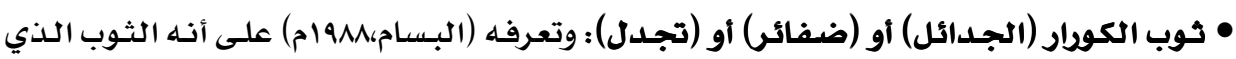

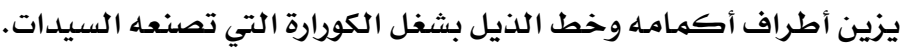

$$
\text { وتضيف (البسام،19M1) مسميات للثياب منها : }
$$

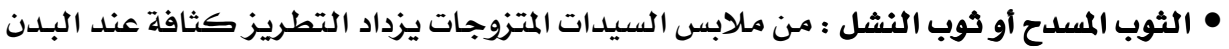

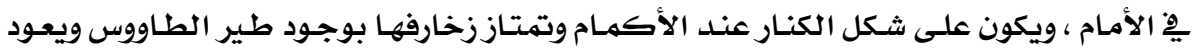

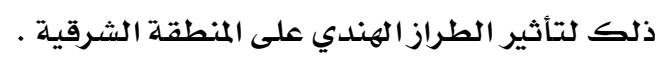

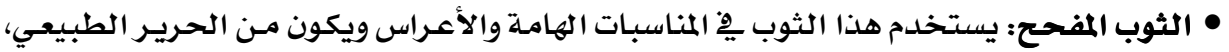

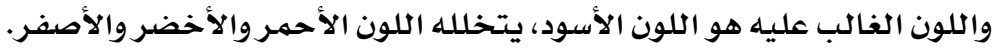

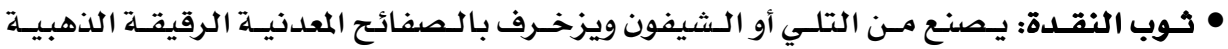

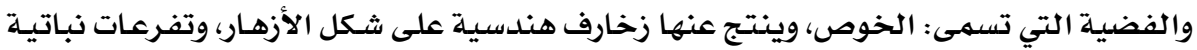

$$
\text { ونقط منثورة تسهىى ( دق المسهمار). }
$$




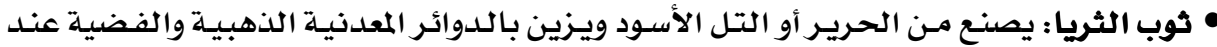

$$
\text { فتحة الجيب على شكل مثلث، وهي من ثياب العربـ اون العروس. }
$$

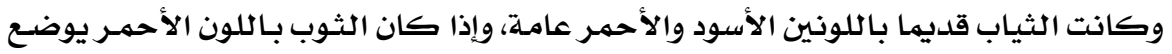

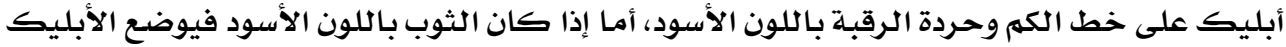

باللون الأحمر.

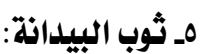

تلبس يٌْ القطيف فوق الثياب عند الخـروج إلى الجـيران والأهل والأقـارب، وعمـر هـذا اللبـاس

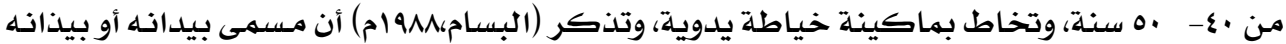

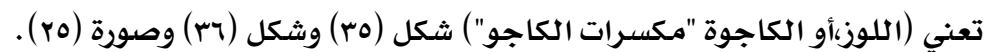

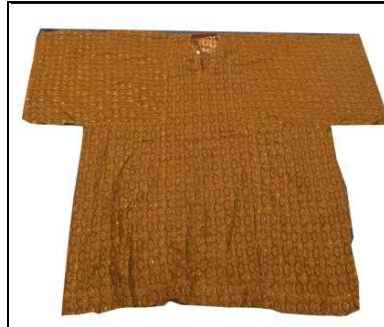

صورة (ro) (n) (1) (n)

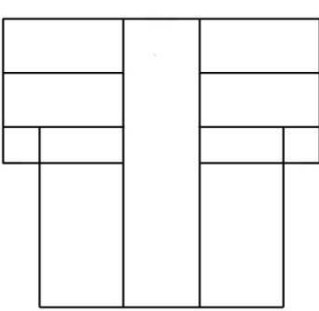

الخلف شكل (جr)

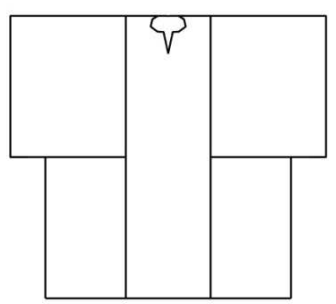

الأمام شكل (ro)

7ـ الثوب الهاشمي السادة :

ارتدت النساء الثوب الهاشهي السادة يِّ القطيف، ويلبس فوق الملابس الصيفية والشتوية

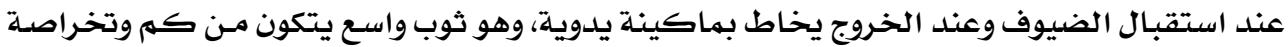

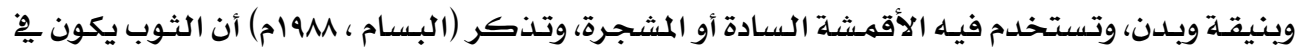

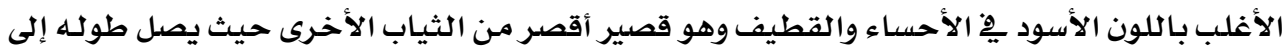

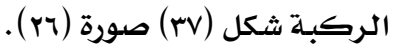

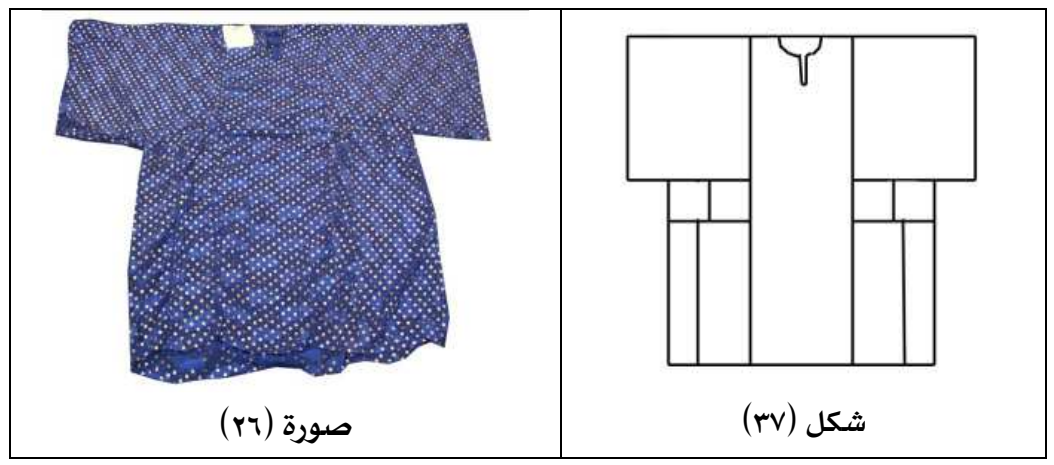




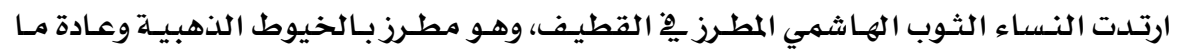

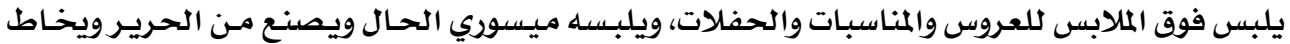

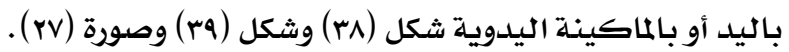

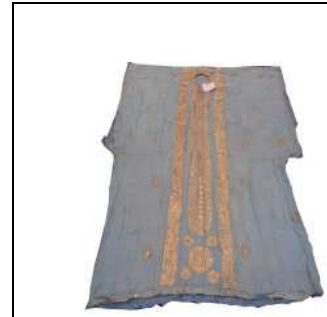

صورة (rv)

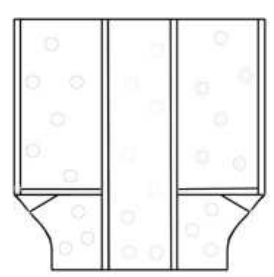

الثوب الهاشمي المطرز من

الخلف شكل (rq)

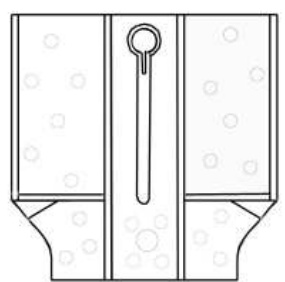

الثوب الها شمي المطرز من الأمام شكل (ی)

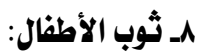

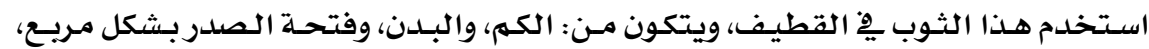

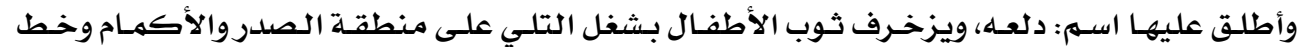

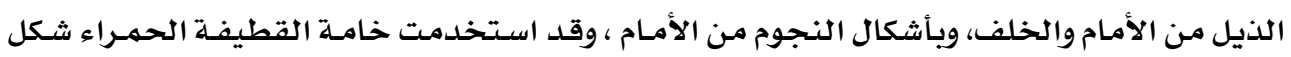

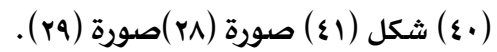

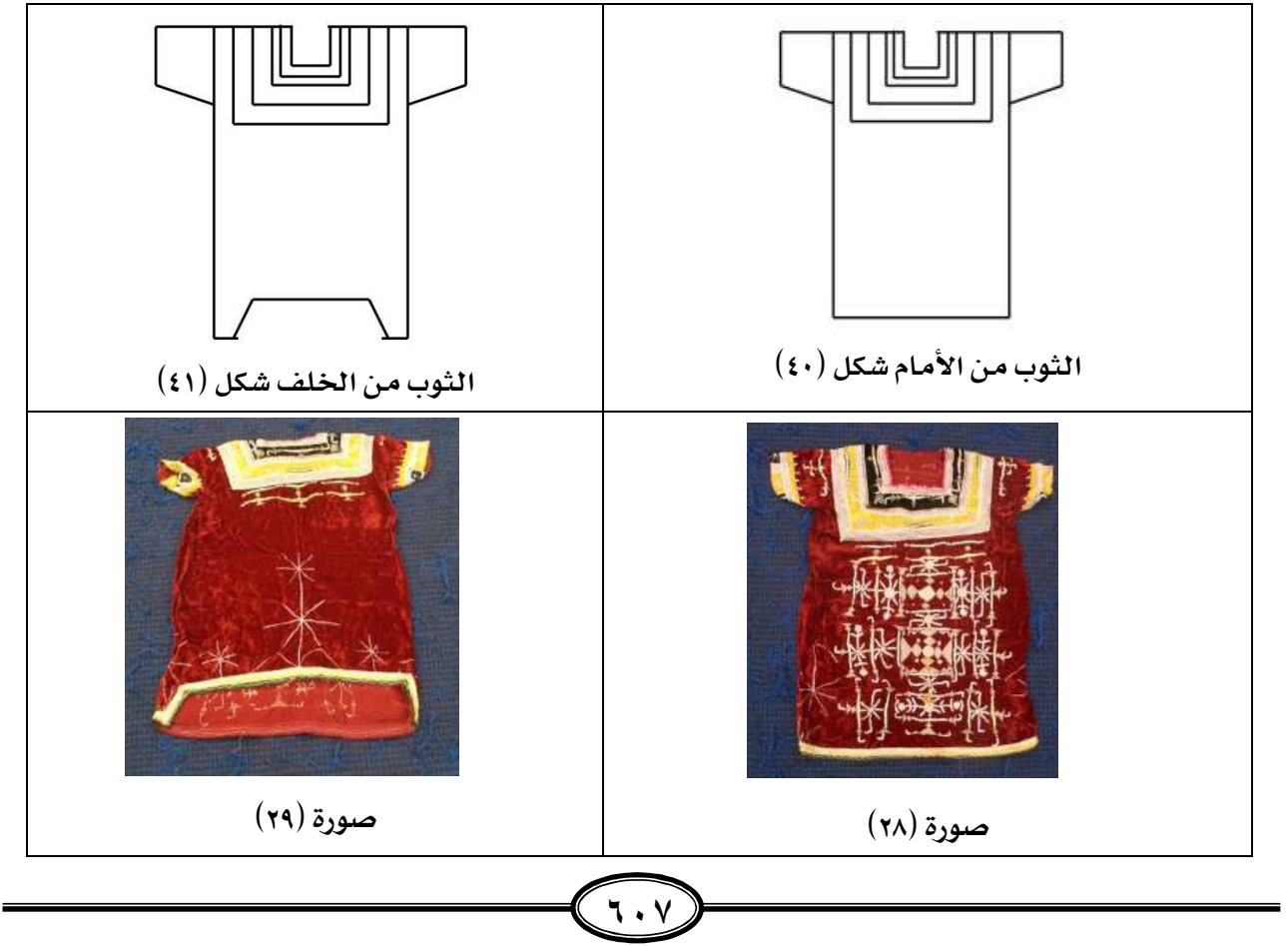




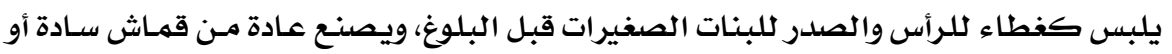

مطرز بخيوط ذهبية للأثرياء أو بالحرير لمتوسطي الدخل شكل (بع ) صورة ( •r).

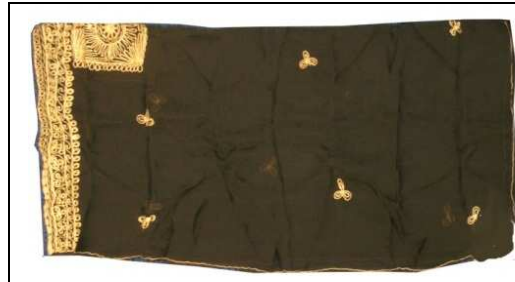

صورة (·r)

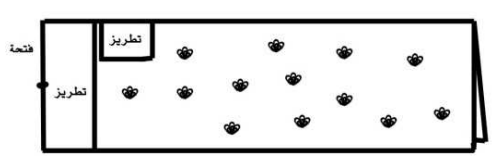

شكل (r؟)

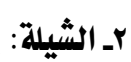

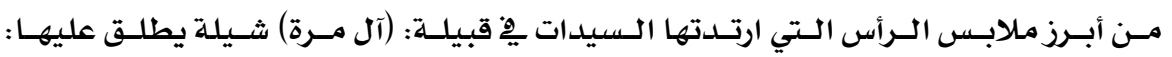

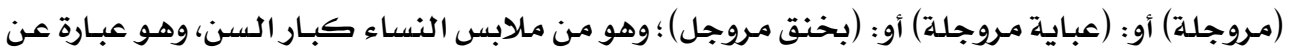

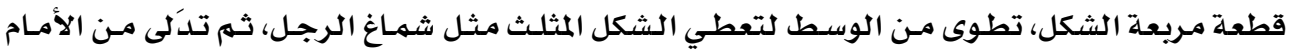

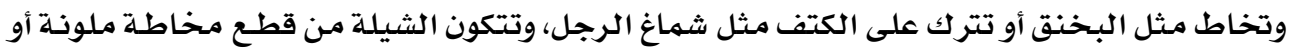
بلون واحد لتكون شكل الشماغ شكل (rع ).

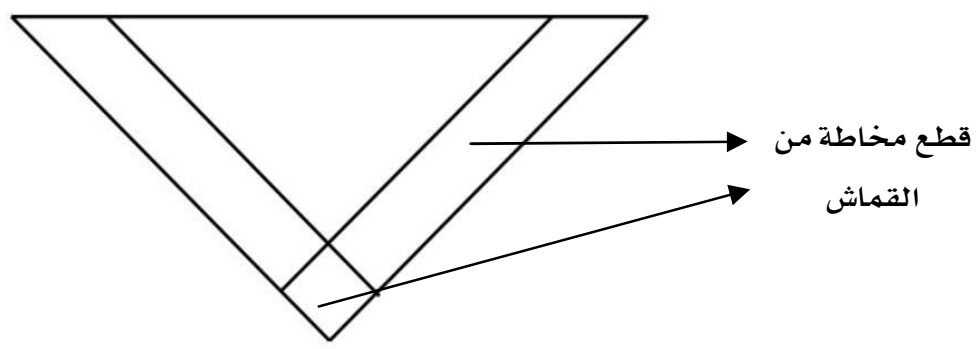

شكل (r)

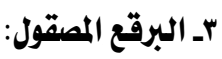

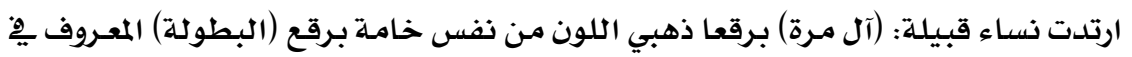

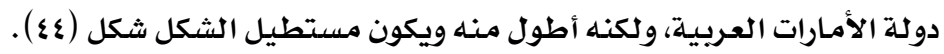




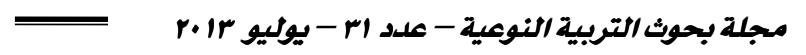

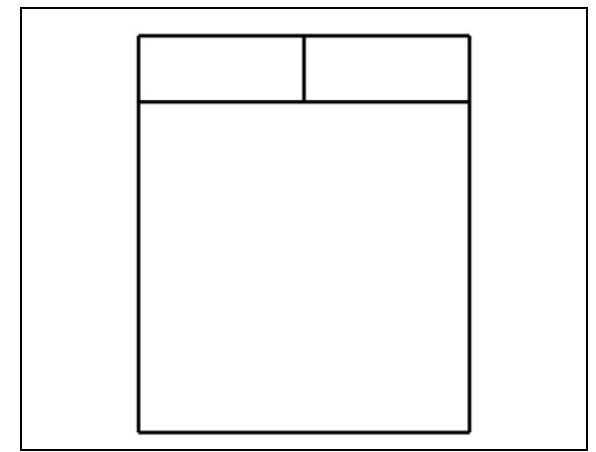

شكل (๕)

\section{هلذص النتائج:}

يمكن تقسيه نتائبج البحث إلى:

ا. أساليب الزخرفة: ويمكن تقسيي الأساليب المستخدمة في تزيين ملابس النساء في المنطقة الشرقية إلى:

أ. التطريز:

ا ـ استخدم التطريز الآلي بكثرة يف المنطقة الشرقية خاصسة تطريز غرزة السلسلة الآليـة،

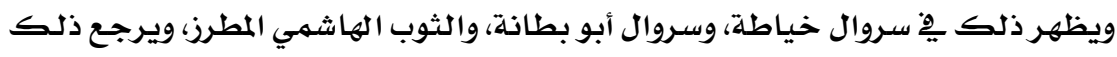

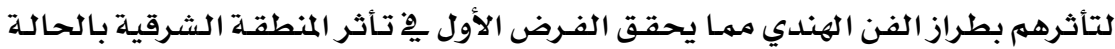

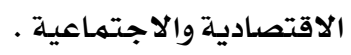

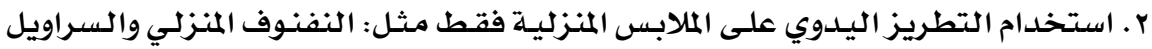

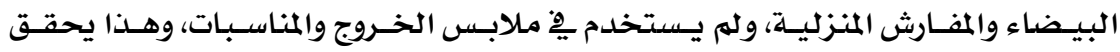

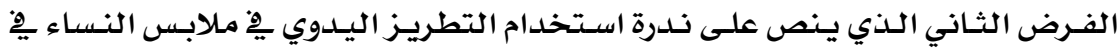

$$
\text { المنطقة الشرقية. }
$$

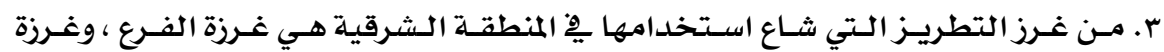

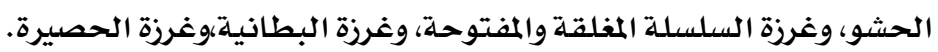

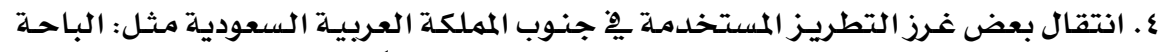

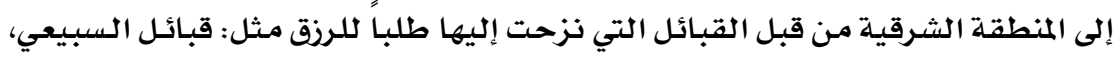

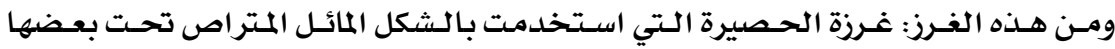

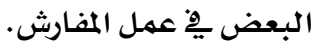

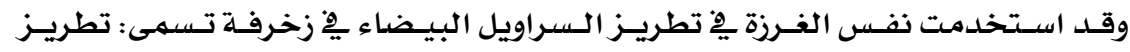

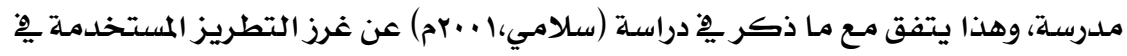

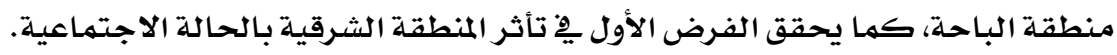




\section{ب- شغل الخنزوزي:}

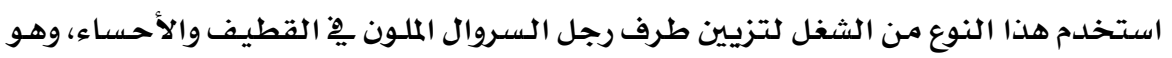

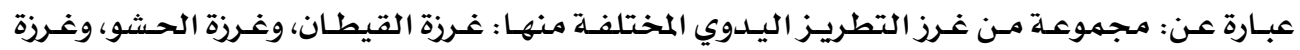

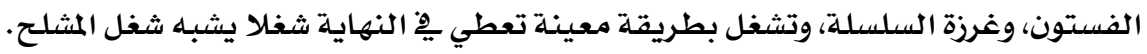

$$
\text { ج- أسلوب الكروشية: }
$$

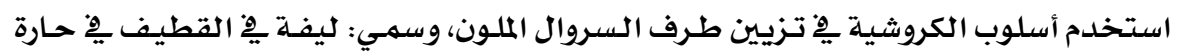

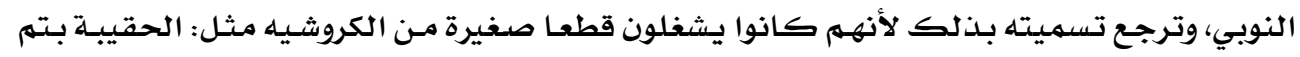

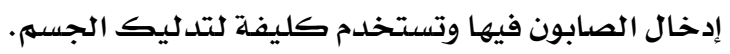

\section{د- شغل الكورارة:}

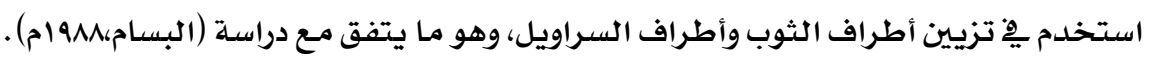

$$
\text { هـ- شغل التلي (البادلة): }
$$

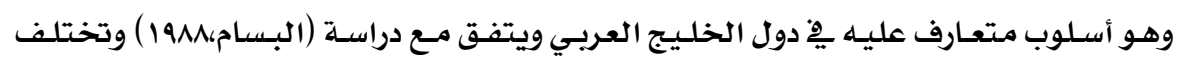

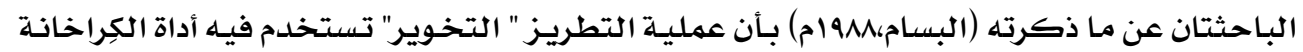

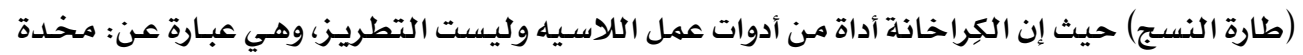

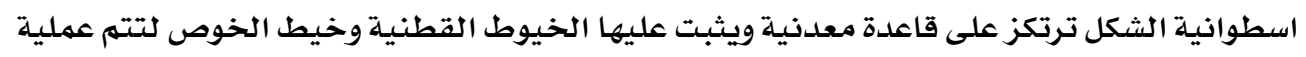

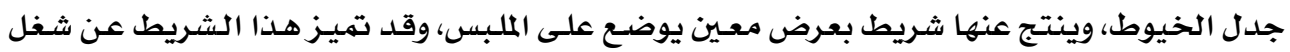

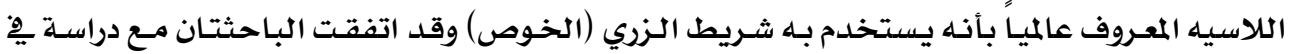

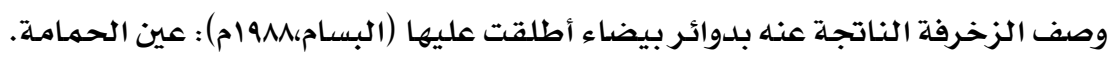

\section{r. الزخارف في المنطقة الشرقية:}

سهي التطريز ِِّ المنطقة الشرقية حسب شكل الزخرفة المستخدمة فيه فمنها:

$$
\begin{aligned}
& \text { 1. مشجر ( أشكال الورد) } \\
& \text { r. r. r. مثريز مدرسة آثكال الوس } \\
& \text { r.وطي الحمامـة } \\
& \text { ع. رسمة الريعانة } \\
& \text { ه. الطارة ( غرزة الآجور) }
\end{aligned}
$$

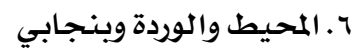

$$
\begin{aligned}
& \text { V. مشكنة وفلس والنجممة }
\end{aligned}
$$

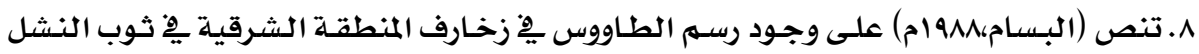

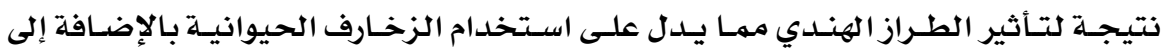

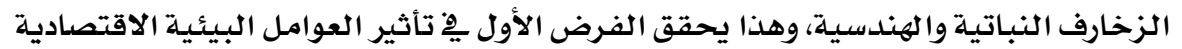




\section{r. المابلاب في المنطقة الشرقية:}

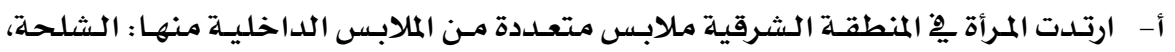

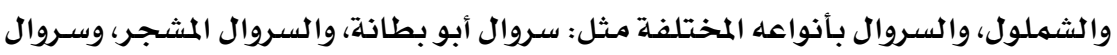

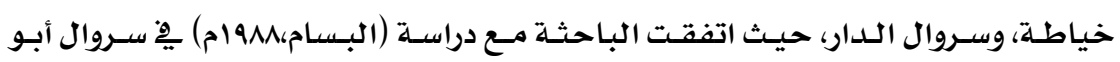
بطانة وسروال خياطة والشملول.

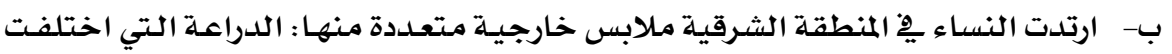

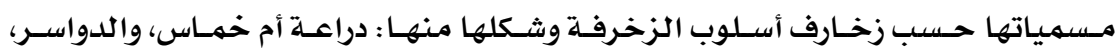
والمخدوم، والنفنوف.

ج- ارتدت النساء ِِ المنطقة الشرقية الثوب الواسع، وتميز عن المنطقـة الوسطى بأنه أقصر

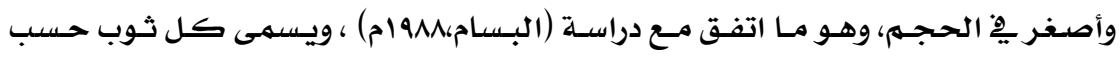

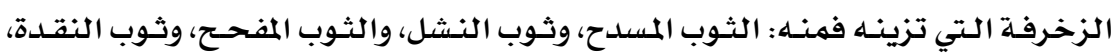

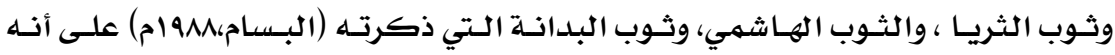

$$
\text { يسهى: البيذانة. }
$$

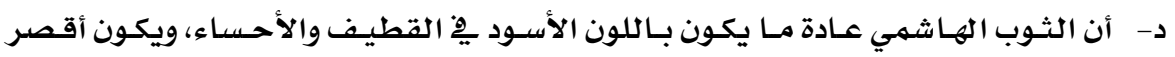

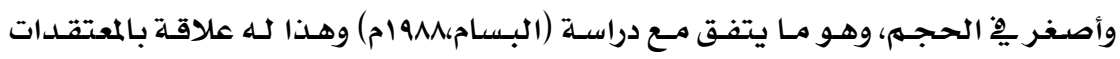

الدينية.

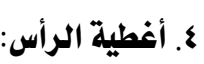

أ- ارتـدى الأطفـال: البخنـق المطـرز آليـاً بغـرزة السلسلة بخيـوط الززري، مزخرفـة بزخـارف

$$
\text { هندسية، ارتدى الأطف }
$$

ب- ارتدت النساء ـِ قبيلة آل مرة: شيلة مروجلة، وهي من ملابس السيدات كبار السن.

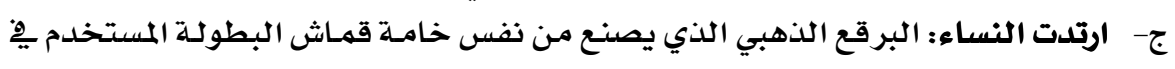

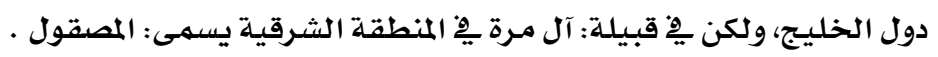


هـ أوجه الشبه بين المنطقة الشرقية والمناطق الأخرى من حيث :

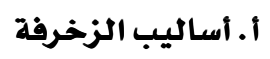

1- التطريز :

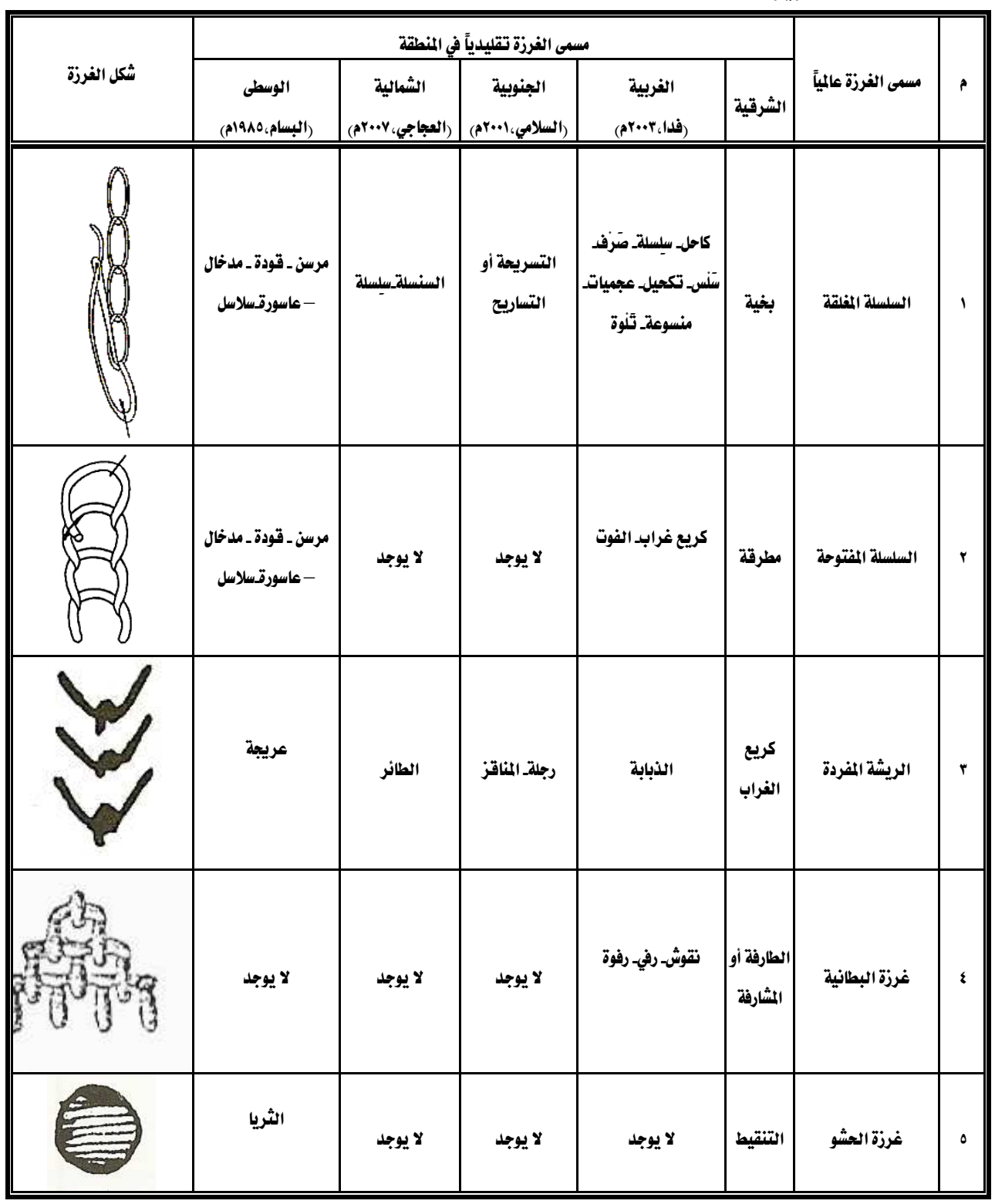




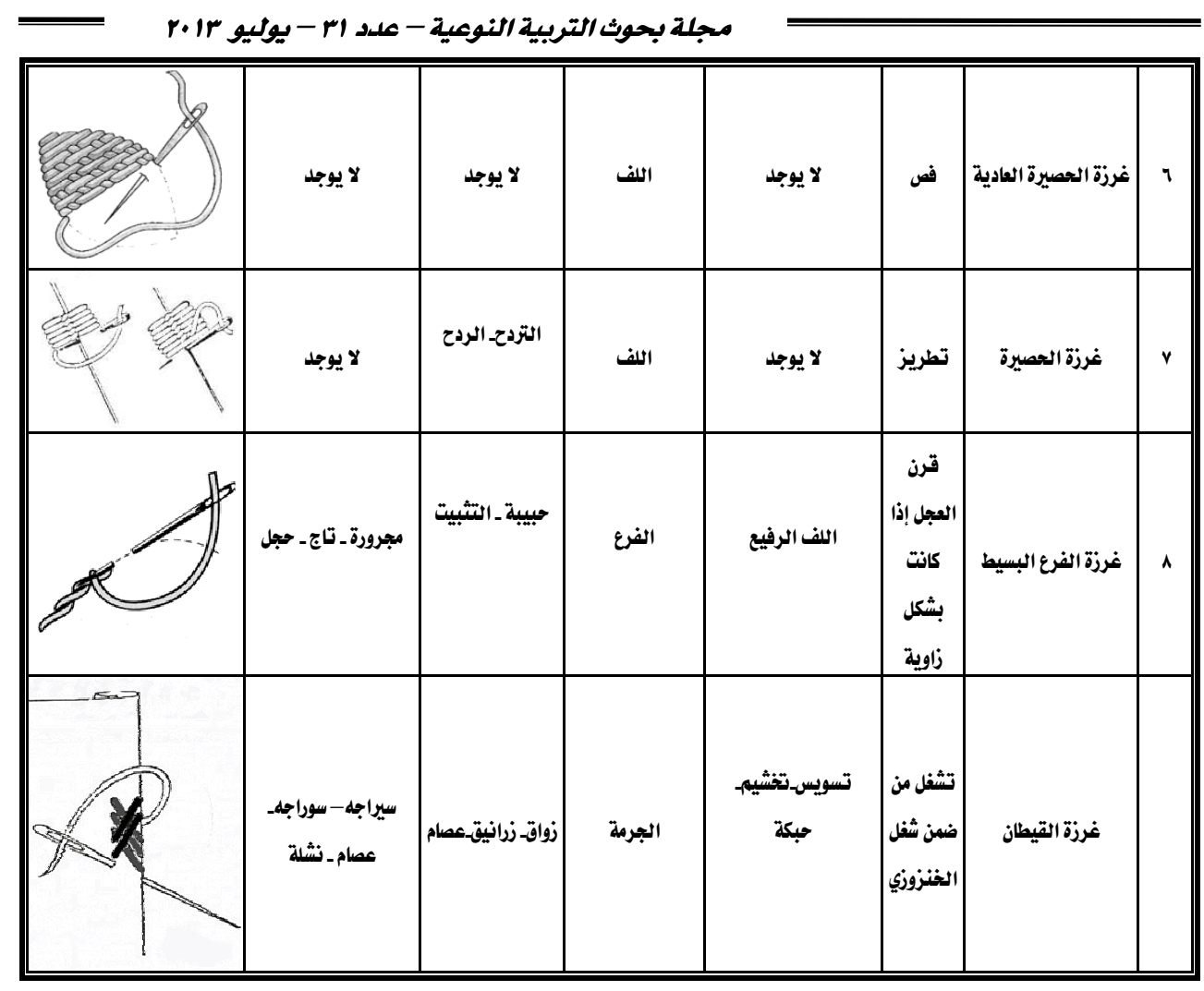

r- الزخرفة :

\begin{tabular}{|c|c|c|c|c|c|}
\hline المنطقة الوسطى & المنطقة الشمالية & المنطقة الجنوبية & المنطقة الفربية & المنطقة الشرقية & A \\
\hline زخارف هندسية ونباتية & زخارف هندسية ونباتية & زخارف هندسية ونباتية & زخارف هندسية & زخارف هندسية ونباتية & \\
\hline
\end{tabular}

r- أنواع الخيوط المستخدمـة:

\begin{tabular}{|c|c|c|c|c|c|}
\hline المنطقة الوسطى & المنطقة الشمالية & المنطقة الجنوبية & المنطقة الفربية & المنطقة الشرقية & P \\
\hline خيوط قطنية - - خ & خيوط قطنية - خيوط & خيوط المسلكة (قطعة مستطيلة من & خيوط قطنية - خيوط & خيوط قطنية - خيوط & \\
\hline خيوط معدنية ذهبية & معدنية خيوط -خيوط & قماش قطني تنسل لتكون خيوط & معدنية ذهبية وفضية & معدنية ذهبية وفضية - & \\
\hline وفضية - خيوط & حريرية & للتطريز) - خيوط قطنية - خيوط & & خيوط حريرية - خيط & \\
\hline 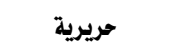 & & حريرية - خيوط صوفية. خيوط & & & \\
\hline & & معدنية ذهبية وفضية & & & \\
\hline
\end{tabular}


ع- القطع الملبسية النسائية بشكل عام:

\begin{tabular}{|c|c|c|c|c|c|c|}
\hline المنطقة الوسطى & المنطقة الشمالية & المنطقة الجنوبية & المنطقة الفربية & المنطقة الشرقية & المطعة & 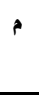 \\
\hline ملونة أو مشجرة & ملونة أو مشجرة & لا يوجد & بيضاء & لا يوجد & الصدرية & 1 \\
\hline كم وطبه التقطع بنصف & لا يوجد & بلابس القطنية & لا يوجد & طويلة للقدم بكم وبلدون & الشلعة & $r$ \\
\hline ملمون & ملون & 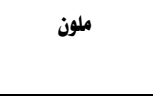 & المدينة بالملون الأبيض في & أشكال مختلفة ابيض & السروال & $r$ \\
\hline الشكل والثوب واسع & مثل مثلثد المثلى التخراصة & مربعة الشكل بتخراصة & مجسم بتخراصة مربعة & الوسطى) التخراصة مثاثة المثلة & الدراعة & $\varepsilon$ \\
\hline واسع وطويل & 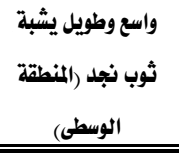 & لا يوجد & واسع وطويل للقدم وبلون & من ثير وأصفر في الحجبم & الثوب الواسع & 0 \\
\hline
\end{tabular}

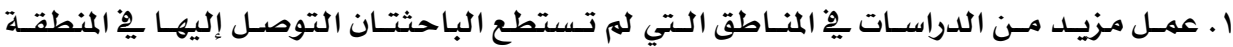

$$
\text { الشرقية. }
$$

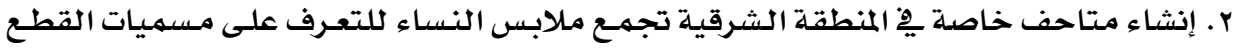

$$
\text { وطرق زخرفتها. }
$$

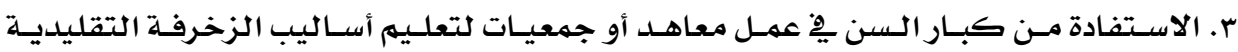

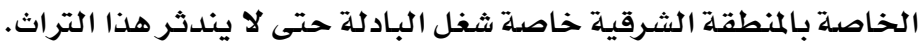

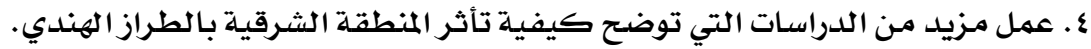

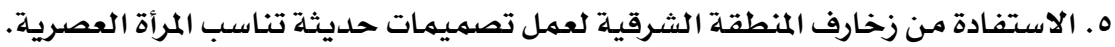


مجلة بحوث التربية النوعية - علد اrr - يوليو rا•r

المراجع:

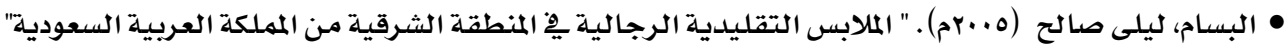

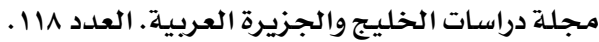

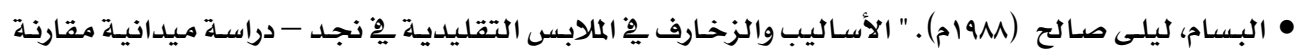
بين ملابس الرجال والنسـاء" رسالة دكتوراه غير منشورة .

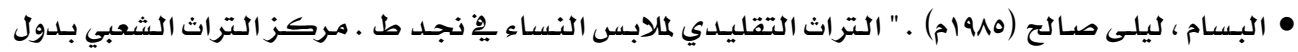
الخليـج العربي .قطر.

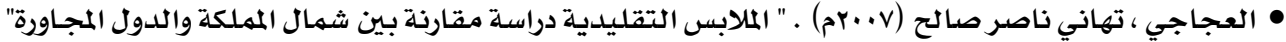
دار الزهراء ـ الرياض. • العزي، نجلـة (جه9 ام)" أنهـاط مـن الأزيـاء الشعبية النسـائية "، مـركز التراث الشعبي لــول الخليج العربي ، قطر

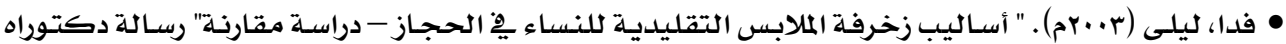
غير منشورة.

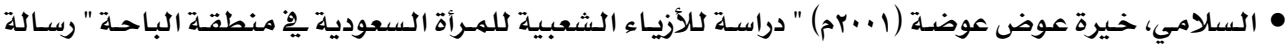

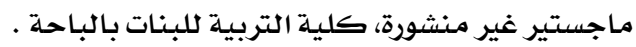

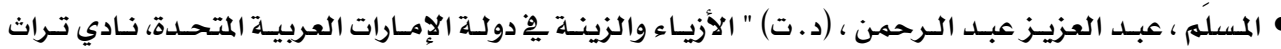
الإمارات. (ها וצ/1/17WWW.alhandasa.nat ) • 